\title{
Revisitando uma carta em português sobre Sabbatai Zvi*
}

\author{
José Alberto Rodrigues da Silva TAvim ** \\ Dpto. de Ciências Humanas - Instituto de Investigação Científica Tropical, Lisboa
}

O folheto impresso que reproduzimos no fim deste artigo foi publicado com grafia moderna por Moses Bensabat Amzalak, em Lisboa, no ano de 1925, num opúsculo designado Shabbetai Sevi. Um carta em português do século XVII em que se testemunham factos relativos à sua vida, antecedendo-o com uma breve notícia sobre aquele personagem. Deste folheto encontrámos dois exemplares na Biblioteca Nacional de Lisboa, um avulso ou fruto de uma miscelânea desmembrada, com a cota R 25345//13P; e o outro inserido numa miscelânea da secção de Reservados, com a cota 903P, contendo outros impressos sobre factos extraordinários ou fantásticos, sucedidos entre os séculos XVI e XIX. Para o organizador da Miscelânea 903P, a notícia sobre o «Messias dos Judeus» possuía um conteúdo tão extraordinário e quiçá fantasista, como o das outras informações à sua disposição, o que explica o seu cabimento num códice cuja organização parece, a princípio, aleatória. Mas para o autor do folheto, seu tradutor e possíveis leitores, o seu carácter extraordinário e fantástico transportava-os mais para o sensacionalismo de eventos presenciados ou bem conhecidos.

Atestando o interesse em Portugal pelo assunto encontra-se na Biblioteca da Ajuda, em Lisboa, um impresso italiano, com o título Lettera mandata da Constantinopla a Roma intorno al nuovo Messia degli Hebrei, talvez o original a partir do qual se produziu a tradução do italiano, como indica o nosso folheto, possuindo o mesmo local de redacção -Constantinopla-e a mesma data-21 de Outubro de 1666- e cujo conteúdo é quase similar ao do folheto em português, resultando as diferenças das adaptações próprias do trabalho de tradução. Se for

\footnotetext{
* Queria agradecer efusivamente aos colegas C. L. Wilke, I. Drummond Braga, J. Castaño, M. García-Arenal, M. Studemund-Halévy, S. Neves da Silva e S. Faroqhi, devido à sua colaboração preciosa, mormente na disponibilização de bibliografia, sem a qual este artigo não seria possível. Para todos eles vai o meu especial apreço.

** tavim.jose@clix.pt
} 
esta a matriz, o nosso folheto será, no mínimo, de 1667, pois é esta a data do folheto italiano, impresso em Ronce(i)glione ${ }^{1}$. Gershom Scholem refere na bibliografia da sua obra sobre Sabbatai, a existência de uma Secunda Traducçam e verdadeira exposiçam de uma carta mandada de Constantinopla a Roma, acerca do fingido Messias dos Hebreus, sem local ou data, que o autor avança ter sido impressa em Lisboa, entre 1667 e $1668^{2}$, e cujo paradeiro desconhecemos. Na verdade, estes folhetos incluem-se num conjunto de relatos similares, cujas relações genealógicas são bastante complexas e de definição difícil, não obstante os esforços de Gershom Scholem.

O especialista em Sabbatai considera que a Relazione curiosissima ed insieme verissima del strano successo del preteso Messia degli Ebrei, il quale cagianò tanta commozione in quella Nazione e terminò poi con farse turco. Lettera mandata di Constantinopla a Roma intorno al nuovo Messia degli Ebrei, dal Padre Beccaranda, Gesuita, impressa em Veneza e Parma, com indicação de autor -Jacob Becherand- deve ser a matriz deste conjunto, embora o folheto não indique qualquer data. Depois, apresentando como primeira das obras anónimas uma Relation de la véritable Imposture du fameux Messie des Juifs. Nomé Sabbatai Sevi Juif naturel de Smyrne maintenant nommé Achis=Aziz Mehemet Aga Turc Portier du Serrail du Grand Seigneur. Escrite de Constantinople le vingt-deuxième Nouvembre 1666 par un Religieux digne de Foy Fidelle Témoin de ce qu'il escrit, et envoyé à un de ses amis à Marseille -texto datado de Avignon, Chez Michel Castel, em 1667, que aproveita abundantemente- considera que a Lettera mandata da Constantinopla a Roma intorno Al nuovo Messia degli Ebrei, editada em Siena e Bolonha, por Giacomo Monti, em 1667, é a primeira versão do opúsculo francês, e que as duas impressões portuguesas são a sua tradução ${ }^{3}$. Contudo, escapou ao autor que o opúsculo em francês é enviado a Marselha, e não a Roma, como acontecia com todos os outros impressos desta genealogia, além do facto de ignorar o impresso de Ronceiglione, semelhante à Lettera impressa em Siena e Bolonha e que, como já referimos, deve ser a matriz do impresso aqui reproduzido. Outro indício fundamental: o texto francês foi redigido em 22 de Novembro de 1666, ao passo que todos os outros são de 21 de Outubro do mesmo ano.

Não é nosso objectivo empreender um estudo codicológico e da origem e ramificação dos numerosos folhetos, cartazes, cartas e outros documentos a favor ou contra Sabbatai, escritos em diversos lugares e de carácter mais ou menos

\footnotetext{
${ }^{1}$ Biblioteca da Ajuda, Lisboa, códice 50-V-36.

${ }^{2}$ Gershom Scholem, Sabbatai Tsevi. Le Messie mystique, 1626-1676, trad. M.-J. Jolivet e A. Nouss (Paris 1983), pág. 916.

${ }^{3}$ Scholem, Sabbatai Tsevi, págs. 910-916. 
preciso ou fantasista, também realizado de forma pioneira e sólida por Gershom Scholem ${ }^{4}$. Mas, como veremos, estas precisões são necessárias quando pretendemos apresentar hipóteses para o interesse sobre o movimento de Sabbatai em Portugal.

$\mathrm{O}$ autor do texto reforça a sua autenticidade acentuando que foi testemunha dos factos acontecidos em Constantinopla, e que consultou pessoas dignas de crédito para tudo o que não presenciou. Na realidade, os dados aqui apresentados correspondem à factologia conhecida -ao contrário de outra informação cuja fantasia é realçada por Scholem ${ }^{5}$ - num teor de «veracidade descritiva» semelhante à do manuscrito mais tardio, e mais detalhado, da biblioteca Inguimbertine de Carpentras -Ragguaglio del Messia delli ebrei riconosciuto da tutto l'ebraismo questi anni pa[ssa]tti nel Levante, il quale ha coronata la sua missione col turbante, a confusione di questi miserabili acciecati dalla loro perfidia ostinatione (s.l.; s.d.)- publicado por Henri Méchoulan ${ }^{6}$. Este facto é fundamental para compreendermos o teor ideológico com que é terminado o texto, e que pode provocar uma polissemia da mensagem.

Curiosamente, quer na Relazione em que é mencionado expressamente o nome do padre Beccaranda, e seus possíveis prolongamentos traduzidos, quer no manuscrito transcrito por Henry Méchoulan, estão presentes elementos da Ordem de Jesus (este último texto pertence a um conjunto designado «Morale et jésuites -1626-1705»). O autor do testemunho reproduzido por Simonsohn ${ }^{7}$ é também um jesuíta. Tal parece revelar o interesse da Ordem por excelência da Reforma Católica em descrever minuciosamente um evento contrário às suas pretensões de protagonismo social e religioso, sobretudo quando este acaba de forma desastrosa, evidenciando o triunfo da Verdade Cristã.

\footnotetext{
${ }^{4}$ Veja-se também, sobre o assunto, Jetteke VAN WIJK, «The Rise and Fall of Shabbatai Zevi as Reflected in Contemporary Press Reports», Studia Rosenthaliana 33 (1999), 7-27.

${ }^{5}$ Scholem, Sabbatai Tsevi, cap. 5.

${ }^{6}$ Henry Méchoulan, «Au dossier du Sabbataisme: une relation italienne du XVIIème siècle», em Sceptics, Millenarians and Jews, ed. D. Katz and J. Israel (Leiden 1990), 185-195.

${ }^{7}$ Shlomo Simonsohn, «Christian Report from Constantinople regarding Shabbetai Sevi (1666)», Journal of Jewish Studies XII (1961), 33-58.
} 
$\mathrm{O}$ autor do folheto traduzido para português reporta-se a acontecimentos passados em Constantinopla (Istambul) em 1666, mas começa por lembrar que os judeus acreditavam que o seu Messias era vindo e que acabaria por se «assenhorear» de todas as monarquias do Mundo. É certamente um eco da potência material do movimento, pois sabemos que Sabbatai nomeou mais de 21 reis, numa emulação dos reis de Israel. Entre estes encontrava-se um antigo marrano português, que fora médico em Esmirna. Na Relation surge a informação que tinha vivido grande parte da sua vida em Bordéus ${ }^{8}$. Esta especificação é omitida, sintomaticamente, na Lettera de Ronceiglione e na tradução portuguesa, embora se insista aqui que os judeus de Constantinopla acreditavam que a Monarquia Judaica acabaria por destruir o Império Otomano e todas as Monarquias do Universo. Parece assim que a omissão do «rei judeu» português serviria para evitar futuras evoluções no meio marrano de Portugal, em termos de adesão ao movimento, ao passo que a insistência na conquista das monarquias estabelecidas resvala para interpretações sobre o carácter maléfico dos indivíduos de outra religião, que estão à espera de vingança, e para a periculosidade dos seus intentos ${ }^{9}$.

Segue-se uma «invenção» da intervenção do profeta Natan Askenazi, que predica a mensagem messiânica a partir de Gaza e não de Alepo, na Síria -como se refere na nossa tradução ${ }^{10}$ - e assinala-se o clima profético e visionário que se vivia em Gálata ${ }^{11}$. É o intróito para uma visão da adesão em massa dos judeus de Esmirna e de Istambul ao movimento de Sabbatai -de tal forma que os primeiros tinham deixado as suas actividades- omitindo dissidências, nomeadamente na capital otomana ${ }^{12}$. Enveredando por esta «leitura» do movimento, mais uma vez se insiste no velho topos da «nação judaica» como nação errada e vingativa. De tal forma que se assinala -sem que a documentação o comprove- que os seguidores de Sabbatai ameaçavam publicamente «Cristãos e Turcos». É descrita a seguir, pormenorizadamente, a detenção violenta de Sabbatai pelos alcaides turcos e a audiência do grão-vizir -Ahmed Koprulu- perante o qual teria renunciado ao título de Messias, facto não auscultado em outra documentação. A hipótese para a sua detenção em Gallipoli, em vez da sua liquidação, seria atribuída apenas à cupidez do grão-vizir, igual à dos barqueiros e do governador de Dardanelos, que exigiam vastas somas aos judeus que pretendiam ver o seu Messias. Ora, parece

\footnotetext{
${ }^{8}$ Scholem, Sabbatai Tsevi, págs. 417-421.

${ }^{9}$ Vide o clássico de Jean Delumeau, La peur en Occident (XIVe-XVIII siècles). Une cité assiégée (Paris 1978), cap. VIII, nº 2 e cap. IX.

${ }^{10}$ Scholem, Sabbatai Tsevi, cap. 3.

${ }^{11}$ Scholem, Sabbatai Tsevi, pág. 588.

${ }^{12}$ Scholem, Sabbatai Tsevi, caps. V-VII. 
que Koprulu foi de facto seduzido pela personalidade de Sabbatai, além de ser um homem moderado ${ }^{13}$.

O autor é também bastante preciso relativamente à ambiência messiânica vivida em Istambul, quando descreve a audiência concedida por Mehemed IV a Sabbatai, estando presentes o predicador principal do sultão (Cheik al-Islam) -Mehemed Vani Effendi-, o governador de Andrianópolis (Caimacam) -Kuru Mustafá Pasha- e outros príncipes e senhores; na negação da messianidade que lhe atribuíam; na sua apostasia perante a possibilidade da pena de morte; e na sua nomeação de «Guarda das Portas do Palácio» (Capidji Bachi), com o ordenado de 150 aspres (6 tostões cada dia). O texto termina com a comum lição moral acerca da obstinação judaica como um dos efeitos da maldição de Deus sobre os Hebreus, avançando que a derrota do seu Messias é mais uma evidência que estão errados e deviam enveredar pela Fé Cristã, a do verdadeiro Messias. A pretensão de se fazer deste episódio uma lição moral sobre a superioridade da Religião Cristã está patente na alusão fantasiosa e paradoxal segundo a qual o «Predicante do Grão-Turco» teria exigido a Sabbatai que ele confessasse em voz alta que não havia outro Messias senão Cristo, tendo aquele anuído solenemente. $\mathrm{O}$ fiel católico aceitaria de boa fé a mensagem, mas que pensaria um converso que acredita no novo Messias, sobre este paradoxo? Tanto que, como se informava no texto, «judeus» haviam fluído a Istambul e a Jerusalém, vindos da Itália, Alemanha, Holanda, Polónia, Transilvânia, Inglaterra, Moscóvia e, sintomaticamente, da Espanha e de Portugal, para se juntarem a Sabbatai.

Henry C. Lea foi dos primeiros historiadores a tecer uma relação entre o movimento de Sabbatai e alguns casos de fuga verificados então em Espanha. Refere o autor que em 1666 os tribunais dos portos passaram a investigar todos os convertidos portugueses que pretendiam embarcar, sendo a sua propriedade retida e examinada, e um relatório enviado para a Suprema. Foi o caso, naquele mesmo ano, de quatro detidos em Barcelona e do almirante Francisco Núñez Redondo, punido em Toledo como judeu, e por conduzir conversos para fora do país ${ }^{14}$.

${ }^{13}$ Scholem, Sabbatai Tsevi, págs. 438-439.

${ }^{14}$ Henry C. LEA, A History of the Inquisition of Spain (New York 1907), vol. 3, págs. 303304. Também menciona esta relação, tendo como base a notícia de Lea, Cecil Roth, Histoire des Marranes, trad. R. Pinhas-Delpuech (Paris 1992), pág. 138. 
Recentemente, Bernardo López Belinchón e Mercedes García-Arenal ampliaram esta evidência das repercussões do movimento de Sabbatai em Espanha. Bernardo López Belinchón centra as suas investigações no caso de Málaga, nos anos sessenta do século XVII, um ponto-chave do comércio mediterrânico, como porto de saída de géneros como o vinho, o azeite e as passas, e de recepção de mercadorias do norte da Europa, e que simultaneamente servia como armazém de produtos para o abastecimento dos presídios norte-africanos como Melilla e Orão, atraindo desta forma uma considerável comunidade de conversos portugueses, e também alguns judeus do Norte de África. Eram também estes os canais de abastecimento livresco dos conversos malaguenhos: recebiam livros de conteúdo judaico de Amesterdão, Livorno, mas também de Tânger. E foram igualmente estes os canais através dos quais chegaram aos portugueses de Málaga notícias sobre o Messias que havia chegado. Em Maio de 1666, o comissário inquisitorial de Málaga escrevia aos inquisidores granadinos precisamente acerca do envio de cartas, gazetas e papéis, desde Amesterdão, Livorno e outros portos, dando avisos sobre o novo Messias que surgira na Palestina. Foi por isso que os conversos portugueses não se escusaram a questionar o judeu Juan Coitiño, proveniente de Alcácer-Quibir mas baptizado em Lisboa, sobre o referido Messias, respondendo este que tal era bem conhecido entre os judeus de Tânger ${ }^{15}$. Manuel Ferro, aparentado à acaudalada Casa Montesinos, e um dos provedores dos presídios do Norte de África, foi um desses integrantes do grupo seguidor de Sabbatai, «alimentado» a partir de Amesterdão e de França ${ }^{16}$. Um dos exemplos de ligação a França, apurado por López Belinchón, é o do malaguenho Diego de Villalón, delatado ao Santo Ofício pelo mercador ambulante António de Castillo, por possuir cartas de portugueses residentes em Peyrehorade, como o próprio Castillo, nas quais se informava que na Turquia se havia levantado um judeu por rei, e que convinha que todos os portugueses que estavam em Castela se deslocassem a França ${ }^{17}$.

Mercedes García-Arenal salienta também esta ligação a França. Informa que Francisco Gomez Romano, parente do doutor Prado, refugiado em França, es-

\footnotetext{
${ }^{15}$ Bernardo J. LóPEz Belinchón, «Aventureros, negociantes y maestros dogmatizadores. Judíos norte-africanos y judeoconversos ibéricos en la España del siglo XVII», em Entre el Islam y Occidente. Los judíos magrebies en la Edad Moderna, ed. M. García-Arenal (Madrid 2003), 89-95 e ID., «Los Criptojudíos españoles y Sabbatai Zevi», em Politica y Cultura en la España Moderna (Cambios dinásticos. Milenarismos, mesianismos y utopías), ed. A. Alvar Ezquerra, J. Contreras Contreras e J. I. Ruiz Rodríguez (Alcalá 2004), 698-701.

${ }^{16}$ Bernardo J. López Belinchón, Honra, Libertad y Hacienda (Hombres de negocios y judios sefardíes) (Alcalá de Henares 2001), págs. 410-411.

${ }^{17}$ López Belinchón, «Los Criptojudíos españoles», pág. 701. 
crevia a correspondentes e parentes de Málaga muitas cartas em que os advertia que na Turquia alguém se declarava rei dos judeus, e que desta forma todos deviam abandonar Espanha e viajar até aos domínios do sultão. Entre os destinatários encontrava-se Melchior Méndez de los Rios, um português detido em Madrid, em Outubro de 1666. Nos seus documentos encontrava-se uma missiva enviada também de Peyrehorade, dando conta de cartas anteriores sobre o «nosso rei», e de outras avalizando-as. Juan Méndez Belisario conta igualmente em 1666 que, com base nessas informações, muitas pessoas haviam deixado Málaga e seus arredores, embarcando para a Itália, tendo ele próprio passado a Bayonne e a Peyrehorade, com intenção de partir para a Turquia. À casa de Bartolomeu Montesinos, em Julho de 1666, chegou um documento impresso em Amesterdão, designado «Lista de los Señores Incredulos, y enjermados de la muy noble y Lucida Sinagoga Portuguesa de Amsterdam». Devemos contudo interrogar-nos sobre os motivos que levaram ao envio desse documento a Bartolomeu Montesinos que, ao contrário de seu irmão e associado Manuel, pretendia fugir para aquela cidade dos Países-Baixos ${ }^{18}$.

Carsten Wilke, no sagaz estudo intitulado «Le 'Messie mystique' et la Bourse d'Amsterdam, le 3 mai $1666 »{ }^{19}$, chegou à conclusão que homens tão poderosos e ricos ali referidos, como António Lopes Suasso ${ }^{20}$ e Isaac Nunes Belmonte ${ }^{21}$, tinham um objectivo singular através deste impresso distribuído na Bolsa e enviado à sociedade dos Irmãos Montesinos, com o seu conteúdo irónico revelando que afinal o castigo a que tinham sido sujeitos pelo Mahamad, por não acreditarem que Sabbatai era o Messias prometido, não teria efeito devido às notícias da sua apostasia; e também devido ao paradoxo de dois dos descrentes fazerem parte da autoridade incriminadora (Henrique Mendes da Silva e António Lopes Suasso). Com esta Lista destinada a parceiros formalmente cristãos, afastados da comunidade judaica oficial, asseguravam que os catorze senhores ali incluídos continuavam fiáveis e dignos de crédito, ao contrário de outros como os Curiel ou os Pereira, imersos na febre messiânica em torno de

\footnotetext{
${ }^{18}$ Mercedes García-Arenal, «Atteintes messianiques au Maghreb et dans la péninsule Ibérique: du nouveau sur Sabbatai Zevi», em Lucette Valensi à l'oeuvre. Une histoire anthropologique de l'Islam méditerranéen (Paris 2002), págs. 237-239; e LóPEZ BeLINCHón, «Los Criptojudíos españoles», págs. 699-703.

${ }^{19}$ Publicado en este mesmo fascículo de Sefarad; agradeço deveras a Carsten L. Wilke a consulta e utilização deste artigo antes da sua publicação.

${ }^{20}$ Sobre António Lopez Suasso veja-se a obra de Daniel M. SwetchinsKi e Loekie Schonduve, De familie Lopes Suasso, financiers van Willem III (Zwollw 1998).

${ }^{21}$ Sobre Isaac Nunes Belmonte e sua família pode ler-se, de R. J. H. GotтHEIL, The BelmontBelmonte Family. A Record of Four Hundred Years (New York 1917).
} 
Sabbatai, enviando capitais ou pretendendo mesmo partir para a Terra Santa 22. Os catorze listados pretendiam então que Bartolomeu, tal como seu irmão, permanecessem na Península, revelando mais uma vez que, tal como acontecia em Amesterdão e em outras comunidades judaicas, as fissuras entre aderentes ou opositores ao movimento de Sabbatai atingiam membros do mesmo grupo e neste caso, também de uma mesma família. Mas o acautelamento dirigido a Bartolomeu Montesinos -e quiçá a outros conversos para quem a lista foi impressa- revela que havia um núcleo importante, em solo peninsular, de pessoas prontas a seguir os mesmos propósitos dos Curiel e dos Pereira. E se não é o caso da Lista acima mencionada, outros textos parecem adequar-se a esta dualidade, dependendo do seu leitor, ou seja, da possibilidade deste acreditar naquilo que estava a ser negado, entendendo-se a negação como uma estratégia de ocultação, ou então como um estado necessário para a assunção suprema.

Como bem salientou R. J. Zwi Werblowsky, se o movimento em favor de Sabbatai continuou a crescer mesmo após a sua prisão, isso deve-se ao facto de todos os judeus saberem que o Messias devia sofrer durante algum tempo antes de se revelar com milagres em todo o seu poder e glória ${ }^{23}$. Se o Messias tinha que descer ao abismo do pecado, ao mal e impureza, com o fim de cumprir a sua missão de levantar os raios de luz divina, a sua apostasia no contexto de uma teologia do paradoxo em versão cabalística ${ }^{24}$ teria o equivalente nas porções dos textos que pretendiam aniquilá-lo como «O Messias».

Em Maio de 1666, o emissário de Málaga escreveria aos inquisidores de Granada, informando-os do envio de algumas cartas, gazetas e papéis oriundos de Salé, Amesterdão, Livorno e outros locais, com notícias sobre o Messias que, segundo diziam os judeus, chegou e se apropriou de toda a Palestina e da Terra de Jerusalém. O que mais preocupava o comissário era a exaltação que essas informações poderiam causar nos ânimos de alguns portugueses residentes em Espanha. Exemplificando, um desses documentos era um opúsculo intitulado Relación del nuebo resucitado profeta hebreo llamado Natan Levi y del motín de hebreos y de la stirpe ysrraelitica los quales de poco tiempo aca se han juntado maravillosamente y como an tomado la ciudad de Meca y sepulcro de

${ }^{22}$ Wilke, «Le 'Messie mystique'». Vide também a referência de García-Arenal, «Atteintes messianiques», pág. 239; e de LóPEZ BELINCHÓN, «Los Criptojudíos españoles», pág. 703.

${ }^{23}$ R. J. Zwi Werblowsky, «Messianism in Jewish History», em Essential Papers on Messianic Movements and Personalities in Jewish History, ed. M. Saperstein (New York and London 1992), pág. 49.

${ }^{24}$ R. J. Zwi Werblowsky, «Sabbatai Sebí», em Moreset Sefarad: El Legado de Sefarad, ed. H. Beinart (Jerusalén 1993), vol. 2, pág. 219. 
Mahoma con otros raros sucesos cuya noticia se funda en relacion y testimonio de personas fidedignas en el modo que de Salé, Jerusalen, Alepo, Constantinopla, afirman. Neste opúsculo, informa-se que do referido povo se levantaram 300.000 pessoas, de diferentes partes, governadas pelo profeta Natan Levi, a quem reconheciam como Messias. Tratava-se de um povo que falava uma língua particular, mas sobretudo o hebraico, cujas armas eram alfanges, arcos, flechas e lanças, e que não estimava as mulheres nem as pretendia em sua companhia. Só ao som das trombetas os muros das cidades sitiadas caíam, o que aconteceu em Meca «donde degollaron a todos escepto a los hebreos, despojaron al sepulcro de Mahoma y lo llevaron consigo en un carro tirado de 36 cavallos». Anunciava-se ainda que Natan Levi tinha enviado um embaixador ao Grão-Turco para que este entregasse a coroa e o ceptro ao novo rei que ele havia ungido, senão destruiria toda a Turquia, e que o sultão havia respondido que o novo rei devia comparecer junto dele, para lhe dar todas as insígnias. Ainda num contexto maravilhoso, avançava-se que segundo as relações e notícias este povo não tinha interesse nem cobiça, que tudo o que tinha era em comum, que seus tratos, géneros e mercadorias eram muito baratos, que seus trajes eram impenetráveis, que nenhuma arma lhe poderia fazer mal, e que seus sapatos nunca se gastavam ${ }^{25}$.

Para além da notória simbiose entre Sabbatai e Natan Askenazi, seu profeta, como já acontecia nas primeiras informações europeias sobre o movimento -fenómeno explicável, segundo Gershom Scholem, devido à dificuldade em pronunciar o apelido do primeiro ${ }^{26}$ - mas também devido ao fenómeno «inventivo» sobre os rumores que vinham do Oriente ${ }^{27}$, interessa-nos salientar outros aspectos neste texto. Em primeiro lugar o facto do autor afirmar a autenticidade de tão extraordinário noticiário, ao asseverar que se «funda em relacion y testimonio de personas fidedignas», e também o seu teor descritivo (nomeadamente da personagem efabulada de Natan Levi), o que aproxima este relato das relações acima referidas, nomeadamente do texto editado por Henry Méchoulan, e da

\footnotetext{
${ }^{25}$ Archivo Histórico Nacional, Madrid (AHN), Inquisición (Inq.), leg. 2647. A maior parte do opúsculo foi publicado por Mercedes García-ArEnAL, «Expectativas mesiánicas en el Magreb y la peninsula Ibérica: entre David Reubeni y Sabbatai Sevi», em Os Judeus sefarditas entre Portugal, Espanha e Marrocos, ed. C. Ballesteros e M. Ruah (Lisboa 2004), págs. 83-84.

${ }^{26}$ Scholem, Sabbatai Tsevi, pág. 209, nota 1.

27 Scholem, Sabbatai Tsevi, cap. 5; e García-Arenal, «Atteintes messianiques», págs. 227231; EAD., «Expectations messianiques», págs. 70-81; EAD., «'Un réconfort pour ceux qui sont dans l'attente'. Prophétie et millénarisme dans la péninsule Ibérique et au Maghreb (XVİ̀-XVII siècles)», Revue de l'histoire des religions 220 (2003), págs. 473-478; EAD., «Les juifs portugais, le Maroc et les Dix Tribus Perdues», Arquivos do Centro Cultural Calouste Gulbenkian XLVIII [= La Diaspora des Nouveaux-Chrétiens] (2004), págs. 161-164.
} 
carta que tratamos aqui, com todos os seus «ascendentes». Em segundo lugar devemos sublinhar que se trata, também, de um texto com carácter dúbio, pois maravilha qualquer leitor com as descrições fantásticas que apresenta, ao mesmo tempo que alerta, desde o início, sobre a falsidade do profeta e a destruição do seu povo: «Al presente es notorio a toda a Alemania y otras probincias y Reinos esta nueba imbencion del falso profeta Natan Levi y del obstinado ysrraelitico pueblo» ${ }^{28}$. A última parte do texto do nuebo resucitado ainda é mais surpreendente. Quase em tom apoteótico, o autor anónimo informa que em todas as partes da Turquia, Pérsia, Polónia, Áustria e Holanda os hebreus falam do seu Messias ${ }^{29}$, e que em Amesterdão muitos já haviam vendido seus bens móveis e de raiz por muito menos do que valiam ${ }^{30}$. Mas logo a seguir reitera que o verdadeiro Messias é Cristo, que os israelitas serão castigados e o seu profeta já clamado não pode ser «senon el demonio para llevar adelante su obstinación y engaño». E no final surge a notícia que a relação foi enviada de Roma a «este señor núncio de España», em língua italiana, estando fielmente traduzida.

Portanto, trata-se de um dos muitos panfletos enviados de Roma para autoridades eclesiásticas do Ocidente, com origem talvez em Istambul, mas reportando-se a um período anterior em que o movimento do Messias ainda estava em marcha. Devia ter sido redigido em 1666, pois Juan Leví, organista na catedral de Málaga, que compareceu perante o Santo Ofício em 17 de Junho desse ano, questionado sobre a Relación del nuebo resucitado, referiu que a letra em que estava escrita era da mão de Andrés Leví de Rojas, seu filho, que se encontrava em Madrid ao serviço de D. Fernando de Ávila Osório, e que a havia recebido há cerca de quinze dias.

Perante este relato, em 30 de Junho, os comissários informaram Madrid que se deveria examinar na «Corte» quem a remeteu. Mas já os inquisidores de Granada, em 18 de Maio, haviam enviado ao Conselho Real os autos sobre as cartas e gazetas que avisavam ter-se levantado um «nuevo Rey de los Judíos»; e depois, em 21 de Junho, especificamente, a Relacion del nuebo resucitado, remetida pelo tribunal de Málaga. A autoridade oficial, nesta cidade, não se

\footnotetext{
${ }^{28}$ AHN, Inq., leg. 2647, publ. GARCíA-ArENAL, «Expectativas mesiánicas», págs. 83-84.

${ }^{29}$ Sobre o assunto vide Scholem, Sabbatai Tsevi, caps. 5 e 6, e também Jacob BarnaI, «La diffusion du mouvement sabbatéen au XVII-XVIII 'e siècles», em La Société Juive à travers l'Histoire, ed. Sh. Trigano (Paris 1993), vol. 3, págs. 309-328; ID., «The spread of the Sabbatean movement in the seventeenth and eighteenth centuries», em Communication in the Jewish Diaspora. The Pre-Modern World, ed. S. Menache (Leiden 1996) págs. 325-337.

${ }^{30}$ Vide Wilke, «Le 'Messie mystique'». 
escusara já em 25 de Maio de 1666 a informar também o rei que o comissário do Santo Ofício da cidade de Málaga havia escrito três cartas de 1, 11 e 15 desse mês, remetendo cartas, gazetas e papéis que tinham chegado às suas mãos, de Amesterdão, Livorno e outros portos, com avisos do novo Messias que «dizen los hebreos que les viene». Como com essas novas se excitavam os ânimos de alguns portugueses que residiam «en estos Reynos», aconselhava que deveria haver prudência régia perante a gravidade do facto. $\mathrm{O}$ mais interessante é que esta documentação foi remetida à corte em 41 faixas acumuladas à «causa de $\mathrm{D}^{\mathrm{a}}$ Mariana portuguesa vizinha de Málaga», e que todo este conjunto informativo, no leg. 26471 da Inquisición, depositado no AHN em Madrid, é encimado por duas missivas mais tardias -a «Copia da carta que o bispo de Málaga enviou ao Inquisidor-Geral», em 14 de Junho de 1672, em que aquele informava que quatro regedores da cidade o tinham avisado como alguns hebreus se ausentaram para Amesterdão e Livorno; e ainda uma «Propuesta de la Ciudad de Malaga», onde surge a referência que de há quatro anos a essa parte saíram mais de quinhentas casas de conversos, e que a semana passada tinham partido mais 40 famílias ${ }^{31}$. Portanto, todos estes avisos à Corte e a correspondência interna entre as diversas autoridades de Málaga e com Granada, levam-nos a pensar que os referidos textos eram considerados elementos de perturbação perante o problema «converso» e, mais incisivo, que aquela Relacion del nuebo resucitado, embora seja iniciada e finalizada com a negação do fenómeno sócio-religioso ali narrado, comportava igualmente elementos considerados susceptíveis de «perturbação». A atestar esta realidade está o facto do texto se encontrar apenso ao processo da conversa $\mathrm{D}^{\mathrm{a}}$ Mariana. Portanto, a polissemia de um texto como a relação do ressuscitado permitiria que a sua leitura fosse filtrada pelos conversos num dos sentidos já acima referidos: considerando impróprios e inverosímeis os vitupérios contra o Povo a que pertenciam e seu Messias condutor, e atendo-se apenas à narrativa dos acontecimentos. Em tempos posteriores, quando se avolumaram as informações sobre a prisão e a apostasia de Sabbatai, àquele primeiro sentido juntar-se-ia uma segunda interpretação, ou seja, que o Messias descera ao fundo do mal para ressurgir em glória...

${ }^{31}$ AHN, Inq., leg. 2648. Vide também García-Arenal, «Attentes messianiques», pág. 229; EAD., «Expectativas mesiánicas», pág. 72; EAD., «'Un réconfort’», pág. 484; EAD., «Les juifs portugais», pág. 163; e LóPEZ-BelinchóN, «Aventureros, negociantes», pág. 94; ID., «Los Criptojudíos españoles», pág. 700. 
Mas voltemos e espiral ao nosso texto e seu contexto social. Porquê a necessidade da tradução impressa do original em italiano? Apenas para alimentar a polémica anti-judaica? Mas o texto parece assemelhar-se mais a uma «reportagem»-se o aproximarmos das formas informativas contemporâneas ... É verdade que está repleto de comentários anti-judaicos, que servem de alicerce à decisão de demonstrar a superioridade do Catolicismo. Mas trata-se mais de um opúsculo informativo que de um tratado de polémica.

Está demonstrado que a circulação desta bibliografia multifacetada em solo italiano, francês e espanhol deriva, por um lado, do interesse jesuítico em informar várias autoridades religiosas e simultaneamente demonstrar o triunfo da Fé Católica; e por outro, no caso de Espanha, surge o interesse de determinadas comunidades judaicas em informar os conversos portugueses que o Messias tinha chegado e era necessário partir para o Oriente. Em contrapartida, como vimos, magnates judeus de Amesterdão que se opunham ao movimento do Messias não se escusavam a um política de contra-informação, dirigida a magnates conversos com quem mantinham negócios. A adesão de alguns cristãos-novos, como os de Málaga, ao movimento de Sabbatai, foi de tal forma intenso que, como verificámos pelo processo de $\mathrm{D}^{\mathrm{a}}$ Mariana, não se escusavam a apropriar-se de textos contrários como o do «ressuscitado Natan Levi», transpondo muito possivelmente para o seu ideário aquilo que era interessante porque importante: o carácter fantasista e maravilhoso do Messias e do Povo que o seguia, e de que eles -conversos portugueses em Espanha- faziam parte. E que informações possuímos para Portugal?

Até agora não apurámos muitos indícios directos sobre o assunto, mas como veremos, alguns são deveras incisivos.

A maior precariedade da informação pode dever-se ao facto do «clima» messiânico -quer na sua face áulica e ligada ao poder, quer na sua face popular- contendo uma pluralidade de mensagens em que podiam rever-se todos os estratos sócio-religiosos em Portugal, bastar ao «corpo» dos conversos portugueses e personalidades e meios afins, como aconteceu anteriormente em volta do sapateiro-trovador Bandarra, condenado pela Inquisição em $1541^{32}$. A

\footnotetext{
${ }^{32}$ Publicação recente das Trovas de Gonçalo Anes Bandarra em Trovas do Bandarra (facsímile da edição de Nantes de 1644), ed. A. Pinto de Castro (Lisboa 1989); e em Profecias de Bandarra [segue também a edição de Nantes de 1644], ed. António Carlos Carvalho (Sintra 2002). Em 1987 foi publicada outra versão das Trovas, a partir da cópia manuscrita do século XVII, pertencente possivelmente a D. Martim Afonso de Melo, bispo da Guarda. Veja-se Adriano Vasco Rodrigues e Maria da Assunção Carqueja Rodrigues, «As Trovas do Bandarra. Suas influências judaico-cabalísticas na mística da Paz Universal», Revista de Ciências Históricas 
edição das suas Trovas, quer por D. João de Castro, em 1603, em contexto de exaltação sebástica ${ }^{33}$, quer pelo marquês de Niza, D. Vasco Luís da Cunha, em 1644 , no contexto da vitória de D. João IV, «herói» da Restauração ${ }^{34}$, são exemplos de como se mantinham actuais, quando «activadas» em torno de uma pretendida personagem messiânica. Este fenómeno de confluência e influência dos messianismos cristão e judaico está consagrado de forma ímpar e diferenciada nas obras de Manuel Bocarro Francês (aliás, Jacob Rosales ou Jacob Hebraeus) (1588-1662) e do padre António Vieira (1608-1697).

Manuel Bocarro Francês estudou Medicina, Astronomia e Matemática em Alcalá de Henares, Sigüenza, Coimbra e talvez Montpellier, exercendo a profissão de médico em Lisboa. Mas sentindo-se pouco seguro devido à vigilância inquisitorial, partiu para Roma, onde estava em 1626, e daí para Amesterdão e Hamburgo, onde viveu entre 1631 e 1652. Em 1653 regressava à Itália, estabelecendo-se em Livorno. Embora Israel S. Révah e José van den Besselaar tenham chamado a atenção para a sua inconstância política e religiosa -passando de «súbdito» português a espanhol- e religiosa -passando do Cristianismo ao Judaísmo- não há dúvida que a sua obra revela, de forma sintomática, esse entrecruzar do olhar judaico e do olhar cristão sobre o Messias, em Portugal ${ }^{35}$.

(1987), págs. 202-221. Bibliografia vasta sobre o assunto. Vide, por exemplo, José Pereira de Sampaio Bruno, O Encoberto (Porto 1904); João Lúcio de Azevedo, A evolução do sebastianismo (Lisboa 1947), com publicação de extractos do processo do Bandarra; O Messianismo em Portugal (Porto, s.d.); Raymond CAntel, Prophétisme et Messianisme dans l'oeuvre d'António Vieira (Paris 1960); ID., «Le Messianisme dans la Pensée Portugaise du XVI ${ }^{e}$ Siècle à nous jours», Arquivos do Centro Cultural Calouste Gulbenkian II (1970), 433-444; António J. SARaIVA, «António Vieira, Menasseh ben Israel et le Cinquième Empire», Studia Rosenthaliana VI (1972), 25-57, republicado in História e Utopia. Estudos sobre Vieira, trad. M. de Santa Cruz (Lisboa 1992), págs. 75-106, versão que aqui utilizaremos; José van den BesselaAR, O Sebastianismo - História sumária (Lisboa 1987), cap. III; Lucette VALEnsi, Fables de la Mémoire. La glorieuse bataille des Trois Rois (Paris 1992), págs. 161-162, 166-168, 174, 185, 192, 201 e 270; Maria J. Ferro TAvares, «Características do messianismo judaico em Portugal», em Estudos Orientais II - O Legado Cultural de Judeus e Mouros, dir. A. A. Tavares (Lisboa 1991), págs. 255-261; Elias LIPINER, O Sapateiro de Trancoso e o Alfaiate de Setúbal (Rio de Janeiro 1993); ID., Gonçalo Anes Bandarra e os Cristãos-Novos (Trancoso 1996).

${ }^{33}$ D. João de CASTRO, Paraphrase et concordancia de algvas prophecias de Bandarra, çapateiro de Trancoso (Paris? 1603).

${ }^{34}$ D. Vasco Luís da Cunha, Trovas do Bandarra, natural da villa de Trancoso. Apuradas e impressas por ordem de hum grande Senhor de Portugal, offereçidas aos verdadeiros Portugueses, devotos do Encuberto (Nantes 1644).

${ }^{35}$ Sobre Manuel Bocarro Francês e sua obra vide Pedro d'Azevedo, «O Bocarro Francês e os Judeus de Cochim e Hamburgo», Archivo Histórico Portuguez 8 (1910) págs. 15-20 e 185-198; Israel S. RÉVAH, «Une Famille des 'Nouveaux-Chrétiens': les Bocarro-Francês», RÉJ XVI (CXVI) 
Em 1624, o autor publicaria a sua Anacephaleoses da Monarchia Luzitana, que foi alvo da atenção do Santo Ofício. No Stado Astrologico, que constitui a primeira e única parte da Anacephaleoses então publicada, Manuel Bocarro, fundado em dados astrológicos e profecias antigas, considera que o Império Mundial está reservado a um monarca português - neste caso o soberano a quem dedica a obra, Filipe IV de Espanha (e III de Portugal), pois a ele cabe a honra de governar a terra lusitana ${ }^{36}$. Em 1626, porém, agentes espanhóis encontraram o manuscrito da quarta parte da sua Anacephaleoses, intitulada Status Heroicus, em que Rosales saudava D. Teodósio, duque de Bragança, como o restaurador de Portugal. Declinando porém este o escudo que lhe era oferecido pela ninfa, foi aceite por seu filho D. João, que seria aclamado catorze anos mais tarde como rei de Portugal, com o título de D. João IV. Este material foi apreendido, o poeta preso, mas devido à intercessão de um amigo influente saiu da prisão e, sentindo-se pouco seguro, acabou por se estabelecer em Roma, onde acabou por publicar este texto com o título de Luz Pequena Lunar e estellífera da Monarchia Luzitana ${ }^{37}$. Pinharanda Gomes é da opinião que o regalismo patente na obra deste e de outros conversos era uma arma de esperança num novo poder que permitisse a liberdade de consciência e, logo, a «desocultação» dos

(1957), págs. 73-87; BesselaAR, O Sebastianismo, págs. 73-75 e 90-92; Jesué Pinharanda Gomes, A Filosofia Hebraico-Portuguesa (Porto 1981), págs 255, 257, 311 e 334; António J. SARAIVA, «Bocarro-Rosales and the Messianism of the Sixteenth Century», em Menasseh ben Israel and his World, ed. Y. Kaplan, H. Méchoulan e R. Popkin (Leiden 1989), págs. 240-243; Francisco Moreno de Carvalho, "Yacob Rosales: Medicine, Astrology, and Political Thought in the Works of a Seventeenth-Century Jewish-Portuguese Physician», Korot 10 (1993-1994), 143156; Michael Studemund-Halévi, «On the Boundaries of our Understanding: Manoel Bocarro Francês - Jacob Rosales and Sebastianism», em Troubled Souls, ed. Ch. Meyers e N. Simms (Hamilton 2001), págs. 65-75; ID., «Rosales, Jacob, alias, Imanuel (Manuel) Bocarro Francês», em Dicionário do Judaísmo Português, ed. de E. Mea, E. Mucznik, L. L. Mucznik e J. A. Tavim (Lisboa, no prelo); Michael Studemund-Halévy e Sandra Neves da Silva, «Tortured Memories. Jacob Rosales alias Imanuel Bocarro Francês: a life from the files of the Inquisition», em The Roman Inquisition: The Index and the Jews. Contexts, Sources and Prophecies, ed. S. Wendehorst (Leiden 2003), págs. 107-151; Sandra Neves da Silva, «Criptojudaísmo e profetismo no Portugal de Seiscentos: o caso de Manuel Bocarro Francês, alias Jacob Rosales (1588/93?-1662-69?)», em Estudos Orientais VIII (Lisboa 2003), págs. 169-183; EAD., «O Físico Imanuel Bocarro Rosales: vestígios da sua presença em Livorno», em Estudos Italianos em Portugal (Lisboa 2005), págs. 63-75.

${ }^{36}$ Manuel Bocarro Francês, Anacephaleoses da Monarchia Luzitana. Anacephaleoses I. Stado Astrológico (Lisboa 1624), fols. $3 \mathrm{v}^{\circ}, 57$ e $65 \mathrm{v}^{\circ}$.

${ }^{37}$ Manuel Bocarro Francês, Luz Pequena Lunar e estellífera da Monarchia Luzitana (Roma 1626). Um extracto foi publicado por J. AzEvedo, A Evolução do Sebastianismo, págs. 161-164. 
conversos e o regresso dos judeus ${ }^{38}$. Foi quiçá a desilusão face à política seguida após a Restauração da independência portuguesa que o levou a defender a posição dos espanhóis e, em 1649, a pedir ao Conselho Municipal de Hamburgo que desse a entender à comunidade portuguesa que devia ser respeitado na qualidade de servidor de «Sua Magestade Católica». Contudo, este autor messiânico nunca deixou de estar directamente relacionado com as organizações judaicas dos locais onde viveu de forma mais permanente: em 1652 assinou o acordo de fundação da comunidade judaica portuguesa «Bet Israel» (Kahal Kadosh Bet Israel) de Hamburgo; e depois do governo espanhol deixar de lhe pagar, e de se estabelecer em Livorno em 1666, tornouse membro da instituição «Hebra de Casar Orfãs» (Hevra di Mohar ha-Betulot) ${ }^{39}$. Podemos pois avançar que a sua obra messiânica e política, essencialmente nacionalista, é o espelho revelador do seu perfil: um converso que pretendia manter-se em Portugal, e que não obstante a necessidade de fuga para o exterior e o assumir da identidade judaica, mirava sempre, nem que fosse no plano utópico, a inserção naquele reino, mas depurado, onde a liberdade de consciência seria possível. Por isso, a base das suas lucubrações foi um messianismo oportunista, de raízes bandarristas, em que abandonava a crença na vinda literal de D. Sebastião, transferindo-a para um príncipe do mesmo sangue, logo emprestando-lhe uma faceta de imediatismo ${ }^{40}$.

Curiosamente, a Anacephaleoses serviu ao padre António Vieira para a defesa do seu ponto de vista acerca de D. Teodósio ${ }^{41}$. Não será ocasional esta posição de Vieira, pois as suas concepções messiânicas e sebásticas estão impregnadas também de uma ideologia regalista que transfere para a pessoa do chefe imediato a tipologia aplicável à pessoa divina do Messias: D. João IV e D. Teodósio são Messias transformados em Déspotas. E também como Rosales, Vieira queria englobar os judeus desgarrados no Império Messiânico de Portugal, embora no seu universo católico:

\footnotetext{
${ }^{38}$ Gomes, A Filosofia, pág. 334.

${ }^{39}$ Studemund-Halévy, «Rosales (Jacob); e Studemund-Halévy e Silva, «Tortured Memories», págs. 149-151.

${ }^{40}$ Studemund-Halévy e Silva, «Tortured Memories», págs. 125-126; e Silva, «Criptojudaísmo», págs. 174-181.

${ }^{41}$ Padre António VIeIRA, Palavra de Deos Empenhada, E Desempenhada: empenhada no Sermam das exequias da Rainha N.S. Dona Maria Francisca Isabel de Saboya; desempenhada no Sermam de acçam de graças pelo nascimento do principe D. João Primogenito de SS. Magestades, que Deos guarde... (Lisboa 1690), págs. 232-236. Agradeço a Sandra Neves da Silva a preciosidade desta informação. Vide ainda Gomes, A Filosofia, pág. 34. Uma boa síntese sobre António Vieira é a obra de José van den BesselaAr, António Vieira: o homem, a obra, as ideias (Lisboa 1981). Vide também João Lúcio d'Azevedo, História de António Vieira, com factos e documentos novos (Lisboa 1918); e Maria J. Ferro TAVARES, «O messianismo na obra do Padre António Vieira», em Terceiro Centenário da Morte do Padre António Vieira. Congresso Internacional. Actas (Braga 1991), vol. I, págs. 135-164.
} 
apoiava-se sobre as profecias do Bandarra para sustentar que os judeus se converteriam, e que a vocação de Portugal era a unificação dos judeus e cristãos sob a mesma fé. Sabemos que em 1646 e em 1647-1648 esteve nos Países Baixos, por ordem de D. João IV, para contactar os judeus portugueses, a fim de obter o seu auxílio financeiro ${ }^{42}$. Enquanto esteve em Amesterdão, Vieira falou com Menasseh ben Israel, que em 1650 redigiria a sua Esperança de Israel ${ }^{43}$. Por sua vez o padre António Vieira, próximo dessa data, escreveria sobre Esperanças de Portugal, $V^{o}$ Império do Mundo ${ }^{44}$, o equivalente à quinta monarquia de Israel no texto de Menasseh, segundo o sonho de Daniel. Ambos os homens partilhavam as mesmas esperanças sobre o protagonismo específico dos seus povos, o regresso das Tribos Perdidas, e acerca de um Messias que seria reconhecido por toda a Humanidade ${ }^{45}$. Mas o mais interessante é que o contacto com Vieira parece ter sido útil a Menasseh para a arquitectura do seu ideário sobre o universalismo messiânico, pois que em 1648, ao publicar a Piedra Gloriosa, considerou que aqueles que não eram judeus, mas que o mereciam e que lhes fizeram bem, gozariam muitas das felicidades com Israel ${ }^{46}$. Por sua vez, o ano de 1666 era esperado por António Vieira como época plena de acontecimentos percursores. Não estaria ele a par das esperanças judaicas sobre Sabbatai, carreadas para esse preciso ano, mas transferindo-as, no contexto do seu Cristianismo, para uma personalidade portuguesa ${ }^{47}$ ?

Portanto, se judeus e cristãos utilizavam tipologias e informações semelhantes, de carácter messiânico, moldando-as depois, de forma diferenciada, às

${ }^{42}$ SARAIVA, «António Vieira», págs. 75-106.

${ }^{43}$ Menasseh Ben Israel, The Hope of Israel. The English Translation by Moses Wall, 1652 [originais Spes Isrealis e Esperança de Israel (Amesterdão 1650)], ed. H. Méchoulan e G. Nahon, trad. R. Georg (Oxford 1987).

${ }^{44}$ Padre António VIEIRA, História do Futuro. Esperanças de Portugal. Quinto Império do Mundo [pensada a partir de 1649], ed. Maria L. Carvalhão Buescu (Lisboa 1982); ID., «Carta ao padre André Fernandes», Camutá, 29.IV.1659, em Cartas do Padre António Vieira, ed. J. Lúcio d'Azevedo (Coimbra 1925), vol. I, págs. 488-547.

${ }^{45}$ CAnTel, Prophétisme et Messianisme, págs. 101-102; SARAIVA, «António Veira», págs. 95-103.

${ }^{46}$ Menasseh Ben Israel, Piedra Gloriosa o de la estatua de Nebuchadnesar. Con muchas y diversas authoridades de la S.S, y antiguos sabios (Amesterdão 1655), pág. 246.

${ }^{47}$ Padre António VIEIRA, Representação Segunda dos Fundamentos e Motivos que tive para me parecer provável o que tratava de escrever acerca do Quinto Império ou Reyno consumado de Christo, em Autos sobre o papel que nesta cidade de Lisboa se divulgou no ano de 1660 sobre a resurreição de El Rey D. João o $4^{o}$ tocantes ao Pe António Vieira religioso da Companhia de Jesus P(reso) no Carçere da Custodia, 1.X.1665, em Defesa perante o Tribunal do Santo Ofício, ed. Hernâni Cidade (Bahia 1957), vol. II, págs. 260-261. Vide ainda SARAIVA, «António Vieira», pág. 101; e Lúcia L. MuczNiK, «Messianismo», em Dicionário do Judaísmo Português, (Lisboa, no prelo). 
pretensões de protagonismo ideológico e religioso das entidades sócio-religiosas ou políticas a que pertenciam, porquê não pensar que «outros leitores» não buscariam em obras de cariz religioso contrário -como a nossa Carta- sinais de uma positividade que se enquadraria nas suas ambições sócio-religiosas? Aliás, sabe-se que em Portugal as polémicas anti-rabínicas eram censuradas se possuíssem argumentos de interpretação positiva para os judeus ${ }^{48}$. De facto, por exemplo em 1622, o converso António da Silva atestaria os receios dos inquisidores ao dizer que o livro do converso João Baptista (d'Este), ao divulgar as cerimónias dos judeus, era bastante favorável a estes, pois que já pouco sabiam delas, acrescentando que as razões que nele se refutavam eram de pouca importância ${ }^{49}$. Mas esse cruzar messiânico ultrapassa os mais limitados círculos eruditos, como já vimos no caso do sapateiro-trovador Bandarra.

Em 1643, o padre António Vieira teria averiguado um cartapácio muito antigo do doutor Diogo Marchão Temudo, a propósito de estrofes repetidas em algumas cópias das Trovas do Bandarra, que analisou e comparou ${ }^{50}$. E o mesmo, perante o Santo Ofício (1665-1666 ${ }^{51}$ ) não deixou de assinalar que os meninos da Beira aprendiam a ler por «treslados» dos seus versos ${ }^{52}$ que, na opinião de José van den Besselaar, exprimiam de forma feliz as secretas aspirações de muita gente

\footnotetext{
${ }^{48}$ Ephraim Talmage, «To Sabbatize in Peace: Jews and New Christians in Sixteenth-Century Portuguese Polemics», Harvard Theological Review 74 (1981), 265-285. E também Israel S. RÉvaH, La Censure Inquisitoriale Portugaise au XVI Siècle (Lisboa 1960), vol. I, págs. 33-34 e 56; e Isaías da Rosa Pereira, Notas históricas acerca de índices de livros proibidos e bibliografia sobre Inquisição (Lisboa 1976) pág. 42.

${ }^{49}$ Instituto dos Arquivos Nacionais/Torre do Tombo (IAN/TT) (Lisboa), Inquisição de Lisboa, livro 204 (Século XvII - Caderno do Promotor $n^{\circ}$ 3), fol. 44-44 vo. O livro referido é a obra de João Baptista d'Este, Consolaçam Christãa, e Luz para o Povo Hebreo. Sobre os Psalmos do Real Propheta David, que prophetizou dos myterios altissimos, que avia de obrar o sancto Rey Messias na redepção do genero humano: com hum discurso muy devoto sobre o Psalmo Beati inunaculati (Lisboa 1616); ou a sua obra mais recente Diálogos entre o discípulo e mestre catequizante onde se resolvem todas as dúvidas que os judeus obstinados costumam fazer contra a verdade da Fé Católica. Com eficacissimas razões, assim dos Profetas santos, como de seus mesmos Rabinos (Lisboa 1620). Sobre a obra de João Baptista d'Este, vide Maria I. Resina Rodrigues, Literatura e Anti-Semitismo. Séculos XVI e XVII (Lisboa 1979) págs. 6-7, 20-21, 27-28 e 36-37.

${ }^{50}$ Vieira, Cartas, vol. I, pág. 531. E ainda TAVAres, «O messianismo», pág. 147.

${ }^{51}$ António Lopes, Vieira O Encoberto - 74 anos de evolução da sua utopia (Cascais 1999), pág. 420, nota 137.

${ }^{52}$ Padre António VIEIRA, Representação dos Motivos que tive para me parecerem prováveis as preposiçoens de que se trata, em Autos sobre o papel que nesta cidade de Lisboa se divulgou no ano de 1660 sobre a resurreição de El Rey D. João o $4^{\circ}$ tocantes ao Pe António Vieira religioso da Companhia de Jesus P(reso) no Carcere da Custodia, 1.X.1665, em Defesa perante o Tribunal do Santo Ofício, ed. Hernâni Cidade (Bahia 1957), vol. I, pág. 149.
} 
portuguesa, agradando ao povo e atraindo a curiosidade de muitos intelectuais. Tal explica a profusão da circulação de cópias, com os inevitáveis erros e deformações $-« O$ carácter popular das Trovas contribuía para haver pouco cuidado em tresladá-las com correcção»)- escreve Besselaar ${ }^{53}$. E ainda em 1675, o marquês de Fontes ${ }^{54}$ seria denunciado ao Santo Ofício pelo familiar António Ferreira, entre outros factos por asseverar que as preposições do padre António Vieira seriam isentas «porquanto erão fundadas em o Bandarra em quem toda esta terra cria athe a prohibição do Santo Officio» ${ }^{55}$. Como assinala Maria J. Ferro Tavares, as Trovas do Bandarra passaram inicialmente a ser divulgadas pelos cristãos-novos de Trancoso, terra daquele trovador. Um Heitor Lopes, tosador, pedira um dia ao sapateiro para as copiar, pois o livro onde se encontravam escritas estava velho. E rapidamente a fama do livro espalhou-se, chegando a Trancoso cristãos-novos de várias regiões do reino, ou consultas por escrito. Mas as suas referências expressas a «Jesus Cristo» como o «Ungido Salvador», com base na tradição milenarista cristã (tinha na sua posse as Trovas de Santo Isidro), fizeram-no imergir do círculo dos conversos ${ }^{56}$, e autor pretendido, desde os «meninos da Beira» até personalidades como Vieira, no contexto das preocupações apocalípticas cristãs ${ }^{57}$.

Um outro caso paradigmático é o dos sucessivos «falsos D. Sebastião», em quem se depositaram esperanças de redenção, no tempo em que aquele ainda podia estar vivo: em 1548 foi sentenciado às galés o falso D. Sebastião de Penamacor; no ano seguinte Mateus Álvares, o «Rei da Ericeira», seria executado; e da mesma forma terminou, em 1595, Gabriel de Espinosa, o «Pasteleiro de Madrigal»; e o último foi Marco Túlio Catizone, o D. Sebastião de Veneza ou Cavaleiro da Cruz, cuja aventura terminou de forma trágica em $15966^{58}$. Em outro contexto, as suas venturas assemelham-se às do Messias Sabbatai... E como vimos, homens de Letras portugueses não

${ }^{53}$ BesselaAr, O Sebastianismo, pág. 52.

${ }^{54}$ Trata-se de D. Francisco de Sá e Meneses, primeiro marquês de Fontes, por mercê de D. Afonso VI, em 1658. Faleceu em 1677. Vide D. António Caetano de Sousa, História Genealógica de Casa Real Portuguesa (Coimbra 1951), t. 9, pág. 263.

${ }^{55}$ IAN/TT, Inquisição de Lisboa, livro 248 (Século XVII - Caderno do Promotor $\mathrm{n}^{\circ}$ 51), fol. $358-358 \mathrm{v}^{\circ}$.

${ }^{56}$ TAVARES, «Características do messianismo», págs. 256-260.

57 LipIner, Gonçalo Anes Bandarra, pág. 42.

${ }^{58}$ Vide Miguel d'Antas, Os Falsos D. Sebastião, ed. Sales Loureiro (Lisboa 1988); Margarida Garcez VentuRA, «O Rei da Ericeira: um entremez de várias esperanças», em Colóquio o Sebastianismo. Política, Doutrina e Mito (sécs. XVI-XIX), ed. Manuela Mendonça (Lisboa 2004), págs. 215-247; e Maria L. Machado de SousA, «Seriam falsos todos os falsos D. Sebastião?», em Colóquio o Sebastianismo Política, doctrina e mito (sécs. XVI-XIX) M. Mendoça (ed.) (Lisboa 2005), págs. 265-276. 
deixaram de catapultar para personagens de protagonismo político iminente as suas esperanças messiânicas de redenção de Portugal, e sobre o seu papel redentor universal.

Portanto, toda esta ambiência messiânica vivida em Portugal, em todos os estratos sociais, pode explicar o interesse em publicar mais um texto de «teor messiânico», em que a Ordem de Jesus assumia o seu papel de vanguarda em manter a ortodoxia, no contexto do ideário oficial sobre o Messias, contra outros messianismos como o estritamente judaico.

\section{IV}

Mas há alguns indícios que permitem avançar que esta «reportagem» (tal como outras da autoria de jesuítas, já mencionadas) tem também um objectivo mais preciso e actual, relativamente ao público para quem foi traduzida (que podia estar de acordo ou claudicar das suas intenções).

Em 29 de Abril de 1669 apresentou-se perante o Santo Ofício em Lisboa, Isabel ou Rosa Mendes Malin, natural da Península Ibérica e residente em Livorno, casada, de 18 anos. Era filha dos cristãos-novos Diogo Nunes Sanches, tratante, e de Maria de Campos. Casara-se com Salomão ou Duarte Mendes Malin, em Livorno, na casa dos tios paternos, Abraão de Castro e Esther de Castro, também oriundos da Península. Foram estes que a mandaram vir da Península, aos 13 anos, educando-a na religião judaica e tratando-a como a filha que não conseguiram ter. Assim que casaram, Isabel e Salomão enveredaram por um longo périplo que incluiu Alexandria, Esmirna e o «Grão-Cairo», por ocasião da nova que «era vindo o Messias». Viajaram depois até Bordéus, pois seu marido procurava forma de sobreviver, e foi aí que um criado do seu pai biológico a advertiu que este ainda vivia em Portugal. Chegados a este país, Diogo Nunes Sanches elucidou-os que não «iam bem encaminhados» religiosamente, apostando Rosa na redução ${ }^{59}$.

A sua procura, em breves anos anteriores, do «Messias», até ao «GrãoCairo» está relacionada logicamente com o movimento de Sabbatai que, em 1662, passou do Cairo a Jerusalém e a que a comunidade de Livorno não ficou

${ }^{59}$ IAN/TT, Inquisição de Lisboa, liv. 711 (Caderno de Reduzidos $\mathrm{n}^{\circ}$ 4), fols. 63-67. Vide ainda Isabel Drummond BRAGA, «Uma estranha diáspora rumbo a Portugal: Judeus e CristãosNovos reduzidos à fé católica no século XVII», Sef 62 (2002), págs. 268-269; e José A. TAvim, «Os Cristãos de Jeová. A História Extraordinária dos Renegados Judeus (séculos XVI a XVII): o caso português», em Revista da Cátedra Jaime Cortesão (USP, Sao Pãulo, Brasil, em publicação). 
indiferente, sendo pelo contrário um dos grandes centros difusores da informação sobre o Messias. Judeus desta cidade enviaram ao Cairo a bela Sara, fugida ainda criança aos massacre dos tártaros e dos cossacos comandados por Bodgan Chmielnicki, e que acabou por casar com Sabbatai em 1664, fascinado pela sua beleza e inteligência ${ }^{60}$. Também não será por acaso que Isabel fala em Esmirna no seu périplo, pois é a cidade natal de Sabbatai, onde retornaria em glória no ano de $1665{ }^{61}$. E se até os cabalistas Moshé Pinheiro e o marrano Abraão Miguel Cardoso foram em Livorno apóstolos deste movimento ${ }^{62}$, porquê não pensar que Isabel e Salomão faziam parte do «cortejo de acompanhantes» de Sara, sua «futura rainha» e marrana, como eles? Mas em 1666, perante o sultão Mehemed IV, Sabbatai foi obrigado a converter-se ao Islão para salvar a sua vida, adoptando o nome de Mehmed Effendi ${ }^{63}$. Verificaram-se então movimentos importantes de oposição a Sabbatai e aos seus apoiantes, mesmo dentro de comunidades em que muitos dos seus membros haviam aderido ao «Messias místico». Por exemplo, em Livorno, os senhores do Mahamad chegaram a legislar em 26 de Outubro de 1676, que quem tivesse contacto, directa ou indirectamente, com o doutor Abraham Cardoso, seguidor de Sabbatai ${ }^{64}$, quem se obstinasse a crer que esta personagem era o Messias e quem tivesse propagado esta crença, seria punido com a mais grave das excomunhões e a mais terrível das maldições ${ }^{65}$. A vida devia teria ficado difícil, em Livorno, para Isabel e seu marido. Porquê não pensar então que enveredaram por um caminho similar ao do Messias procurado no «Grão-Cairo», mas na Península onde vivia o pai daquela? É que o profeta Natan de Gaza tinha tecido uma explicação cabalística para a apostasia do seu Messias, mencionando que aquele havia descido ao fundo da «klipa» (o outro lado, das forças demoníacas, neste caso o Islão), para melhor combater as

\footnotetext{
${ }^{60}$ Scholem, Sabbatai Tsevi, págs. 198-199.

${ }^{61}$ Scholem, Sabbatai Tsevi, cap. $4, \mathrm{n}^{\circ} 5$.

${ }^{62}$ Renzo ToAff, La Nazione Ebrea a Livorno e a Pisa (1591-1700) (Firenze 1990), págs. 368-369.

${ }^{63}$ Scholem, Sabbatai Tsevi, cap. 4.

${ }^{64}$ Sobre Abraham Cardoso, vide Scholem, Sabbatai Tsevi, cap. 7, n X; Isaac R. Molho e Abraham Amarillo, «Autobiographical Letter of [Abraham] Cardoso» (em hebraico), Sefunot III-IV (1959-1960), 183-241; Yosef H. Yerushalmi, From Spanish Court to Italian Ghetto. Isaac Cardoso: A Study in Seventeenth-Century Marranism and Jewish Apologetics (New York 1971), cap. VII; e Harm den Boer, La literatura sefardí de Amsterdam (Alcalá de Henares 1995), págs. $87,92,96$ e 123.

${ }^{65}$ «La legislazione fra il 1655 e il 1671», doc. 9 em ToAfF, La Nazione Ebrea, págs. 592-593. E ainda sobre o assunto, págs. 370-371.
} 
forças do mal ${ }^{66}$. E acontece que Natan esteve em Livorno no ano de $1668{ }^{67}$. Zwi Werblowsky chamou a atenção que teólogos como Natan de Gaza e, mais tarde, Abraham Cardoso, consideraram que os actos levados a cabo pelo Messias formavam parte do Mistério Messiânico, mas que não deviam ser imitados. Outros, contudo, asseguravam que era necessário adoptar uma atitude antinómica (como a da própria «licenciosidade sexual»), e inclusive apostatar como o Messias. Foi assim que um grupo de 300 crentes apostataram em Salónica, no ano de 1683, convertendo-se numa seita pseudo-muçulmana, estritamente endogâmica: são os «doenmeh» ${ }^{68}$. Nesta sequência, não será melhor mergulhar apara além da aparente ingenuidade do texto de redução de Isabel e pensar que em Portugal esta procurava, também, descer ao fundo da «klipa», juntando-se depois ao seu Messias reforçado?

Mas outros foram acusados como transmissores ou receptores de novas sobre Sabbatai. Em 7 de Setembro de 1666, o jesuíta António de Melo escreveria um memorando contra Cristóvão de Melo, governador da praça de Mazagão ${ }^{69}$, por se intrometer na jurisdição eclesiástica. Entre os elementos apresentados surge uma longa referência ao episódio de rabi Samuel, natural de Azamor, «tido entre os Judeos desta Mauritania por Rabbino, e sabio, e o he toccante a inteligencia material e literal do testamento velho». O rabi tinha viajado até Mazagão, devido a um negócio que mantinha com Cristóvão de Melo. Porém, o jesuíta soubera que rabi Samuel falara ao governador sobre o «embuste» de um «falso Messias que tinha aparecido nas partes do Levante», e logo se dirigiu ao judeu, para saber pormenorizadamente o que lhe havia dito. Para o jesuíta, o assunto era muito grave: exigiu, junto de Cristóvão de Melo, que este obrigasse o judeu, sob pena de morte, a não divulgar o assunto a mais ninguém, o que foi cumprido -segundo assevera o jesuíta. A seguir transcreve o que foi contado por rabi Samuel. Disse este que em Jerusalém nascera há 40 anos um menino cujos pais pertenciam à Tribo de David, permanecendo sadio até à idade de 7 anos. Contudo, desde então e até aos 32 anos, ficara enfermo. Mas atingindo essa idade, juntaram-se muitos sábios e rabis na sua casa e, falando-se do Messias, disse

\footnotetext{
${ }^{66}$ Scholem, Sabbatai Tsevi, pág. 135, 142, 203, 298-323, 689-690, 795-796; e Zwi WerblowsKY, «Sabbatai Sebi», pág. 219.

${ }^{67}$ Scholem, Sabbatai Tsevi, pág. 749.

${ }^{68}$ Zwi Werblowsky, «Sabbatai Sebi», pág. 222. Sobre os «doenmeh», vide, por exemplo, Gershom Scholem, The Messianic Idea in Judaism and Other Essays on Jewish Spirituality (New York 1971), págs. 142-166.

${ }^{69}$ Sobre acapitania de Cristóvão de Meloem Mazagão, vide Luís Maria do Couto de Albuquerque da CunHa, Memórias para a História da Praça de Mazagão, ed. Levy Maria Jordão (Lisboa 1864), págs. 93-94; e Augusto Ferreira do Amaral, História de Mazagão (Lisboa 1989), págs. 160-161.
} 
o rabi de maior reputação que ali estava ele, ou seja, «que naquella casa estava o seu Messias». Os outros presentes disseram-lhe que o declarasse. Foi então que se abriu o tecto da casa e desceu do Céu um resplendor sobre o enfermiço, vendose pelos quatro cantos da casa resplendores semelhantes. O paxá de Jerusalém, no encalce do "arruído da novidade», pediu milagres para que se confirmasse ser aquele o Messias: que o «descuberto» desse vista a um cego e pés a um coxo que ali se encontravam. Acontecendo o pretendido, o paxá reconheceu-o como o Messias e avisou o «Gran Senhor de Constantinopla» do que se passava. E logo à vista de todos desceu um anjo do céu, com uma rodoma, e o ungiu, e colocou na sua mão a vara de Moisés, a seu lado o alfange de Josué, e na cabeça a coroa de David. Informou também o rabi que Moisés e Elias lhe assistiam, que a sua fama se havia espalhado por toda a Palestina, e que mais de 80 profetas andavam pelas cidades daquelas regiões, pregando a sua vinda. Mais ainda, que o «Gran Turco» o esperava «com alvoroço», com o intuito de lhe sujeitar o seu Império, e que Chipre e as mais ilhas do Arquipélago, Damasco, Egipto, Arménia e muitas outras províncias do Levante o tinham reconhecido ${ }^{70}$.

Logicamente que estamos mais uma vez a lidar com uma «construção fantástica» sobre traços de uma realidade que podemos reconhecer. Mas essa «construção fantástica» possuía a virtude de atrair ainda mais os interessados por tão extraordinário evento. Pelo texto nota-se que o rabi estava informado sobre a patologia psicológica de Sabbatai, mas aqui transformada com o carácter de «incubação»e «descoberta messiânica», já «trabalhado» in loco pelo próprio profeta do Messias místico ${ }^{71}$.

A construção fantástica, com base nos rumores, acrescentou outros atributos a Sabbatai, que o tornaram mais convincente. Seria da Tribo de David, de onde havia de sair o Messias esperado. Foram os sábios e os rabis que «descobriram» o Messias em Jerusalém -e não em Esmirna, terra natal do Messias místico. Os resplendores e a «entronização» pelo anjo, e o facto de ser auxiliado pelos grandes profetas Moisés e Elias, emprestavam uma áurea de «autenticidade espiritual» à personagem «construída». Por outro lado, o reconhecimento pelo paxá de Jerusalém e a alusão que o sultão da Turquia esperava ansiosamente por lhe entregar os seus domínios, a que seriam acrescidas as outras regiões mencionadas do Levante, corresponde a uma informação «filtrada» das pretensões realistas de Sabbatai e seus seguidores sobre a instauração do reino messiânico, a partir do Oriente -e daí que Sabbatai e os seus seguidores se tivesses dirigido a Istambul

${ }^{70}$ IAN/TT, Inquisição de Lisboa, livro 243 (Século XVII - Caderno do Promotor $\mathrm{n}^{\circ} 46$ ), fol. $59-59 \mathrm{v}^{\circ}$.

${ }^{71}$ Scholem, Sabbatai Tsevi, cap. 2, II. 
no ano de $1666^{72}$. Os milagres atribuídos ao Messias no relato do rabi Samuel remetem igualmente para outras informações sobre um «clima especial», ou seja, em que acontecimentos extraordinários alteravam a ordem natural, em torno daquele personagem. Num opúsculo que foi publicado em Londres em 1665, uma carta enviada de Salé, em Agosto desse ano, mas com notícias provenientes do Suz, mais propriamente de Agadir, confirmava a marcha das Dez Tribos de Israel, estacionadas então por altura daquela cidade, e cujo chefe, que se encontrava à sua cabeça, realizava milagres, lia nos espíritos e sondava os corações de todos aqueles que se aproximavam ${ }^{73}$. Entre as cartas recebidas pelo português Melchior Méndez de los Ríos, preso em Madrid em 1666, encontrava-se uma enviada de Peyrehorade, por um dos seus filhos, informando que havia recebido carta de um alemão que estivera em Constantinopla, referindo que os judeus organizaram um grande jubileu, pois a partir de 11 de Agosto começaram-se a ver milagres. Em outra missiva enviada de Esmirna por certos flamengos, provavelmente conversos, dizia-se que a situação era favorável aos judeus e que haveria numerosos milagres nesse ano ${ }^{74}$.

O relato de rabi Samuel continua triunfante, expondo o apoio recebido pelo Messias. Disse ao jesuíta que sem se saber de onde, se lhe juntaram inumeráveis multidões de soldados e cavalaria, e que sem força nem insolência se lhe sujeitavam todos ao seu domínio ${ }^{75}$. Trata-se de outro topos que remetia para a iminência do reino messiânico, e que pode ser apurado em outros relatos, mesmo de carácter perjurativo, como a Relación del nuebo resucitado, em que como vimos se apontavam as miríades de seguidores de «Natan Levi»e que só ao som das trombetas os muros das cidades sitiadas caíam ${ }^{76}$.

Aqui termina a narrativa do rabi, atestada por cartas e avisos «autênticos» que prometeu trazer ao jesuíta, o que não foi cumprido. Mas António de Melo apressou-se a apurar outros indícios. Informou assim como os cristãos da «Berberia» o avisaram dos grandes e rigorosos jejuns que os judeus tinham feito, publican-

\footnotetext{
${ }^{72}$ Scholem, Sabbati Tsevi, cap. 4, VII.

${ }^{73}$ The Last Letter to the London Merchants and Faithful Ministers concerning the further Proceedings of the Conversion and Restauration of the Jews (Londres 1665), publ. Scholem, Sabbatai Tsevi, págs. 339-340. E ainda García-ArenAL, «Un réconfort», pág. 475; EAD., «Atteintes messianiques», págs. 228-229; EAD., «Expectativas mesiánicas», págs. 72-73; EAD., «Les juifs portugais», págs. 162-163.

${ }^{74}$ García-Arenal, «Attentes messianiques», pág. 237; e LÓPEZ-Belinchón, «Los Criptojudíos españoles», pág. 702.

${ }^{75}$ IAN/TT, Inquisição de Lisboa, livro 273 (Século XVII - Caderno do Promotor $\mathrm{n}^{\circ}$ 46), fol. $59 \mathrm{v}^{\mathrm{o}}$.

${ }^{76}$ AHN, Inq., leg. 2647, publ. García-Arenal, «Expectativas mesiánicas», págs. 83-84.
} 
do ser essa a primeira disposição para se salvarem no conhecimento e obediência do «falso Messias» ${ }^{77}$. Curiosamente, tal relaciona-se com as notícias mais tardias transmitidas por Germain de Muette: segundo este, os judeus de Salé, após terem recebido profecias de Amesterdão sobre o Messias que devia chegar em 1672, regozijaram-se e celebraram 8 dias durante uma segunda festa dos Tabernáculos ${ }^{78}$.

Ainda segundo o padre, diziam os judeus que os povos que concorriam para formar os exércitos «desta monstrozidade» eram os tártaros, os quais fingiam ser as nove tribos e meia que se perderam no tempo de Nabucodonosor - «E pera assim ditarem o seo fingimento dizem que os Tartaros nem são mouros nem christãos, e que não tem outro acto de religião senão guardarem o sabbado. E querem os rabbinos que daqui se colha quem sam as Tribos Perdidas» ${ }^{79}$. Talvez ecoe aqui a história dos reis judeus Khazares do Daghestan e da Crimeia, destroçados no século XIII pelas hordas mongóis. Mas o mais lógico é que se estabeleça uma relação com os mais recentes massacres provocados pelos tártaros, no século XVII, que levariam a grandes deslocações de judeus da Ucrânia e da Polónia -como foi o caso de Sara, esposa de Sabbatai. Os rumores que chegavam a Marrocos talvez mesclassem num cadinho propício os «terríveis» tártaros e os judeus deslocados. E quiçá a história inventiva recriasse os «terríveis» tártaros contemporâneos com os traços dos antigos Khazares cujo território agora ocupavam, e dos judeus que fugiam ante o trote dos seus cavalos ${ }^{80}$. De qualquer forma, prevalece neste parágrafo algo semelhante a outros textos sobre Sabbatai, já referidos acima, e que o jesuíta prefere adjectivar no seu universo conceptual como «monstruosidade», o seja o carácter invencível e em geral extraordinário do povo apoiante do Messias: ali são os tártaros que se tornaram judeus; na Relación del nuebo resucitado são o povo «estraño y desconocido», que não estimava mulheres nem as permitia em sua companhia, um mar de gente de 300.000 pessoas ${ }^{81}$; na carta enviada de Salé, em 1665, são as 8.000 companhias ou tropas, cada uma com 100.000 homens, cobrindo uma vasta ex-

${ }^{77}$ IAN/TT, Inquisição de Lisboa, livro 243 (Século XVII - Caderno do Promotor $\mathrm{n}^{\circ} 46$ ), fol. $59 \mathrm{v}^{\circ}$.

${ }^{78}$ García-Arenal, «Un réconfort», pág. 478; EAd., «Atteintes messianiques», pág. 230; EAD., «Expectativas mesiánicas», págs. 73-74; EAD., «Les juifs portugais», págs. 164-165.

${ }^{79}$ IAN/TT, Inquisição de Lisboa, livro 243 (Século XVII - Caderno do Promotor $\mathrm{n}^{\circ} 46$ ), fol. $59 \mathrm{v}^{\circ}$.

${ }^{80}$ Isaac Ben-Zvi, Les tribus dispersées (Paris 1959), págs. 79-81; Scholem, Sabbatai Tsevi, págs. 198-201.

${ }^{81}$ AHN, Inq., leg. 2647, publ GarcíA-ArenaL, «Expectativas mesiánicas», pág. 83. 
tensão de terra, e que pareciam também afastar a companhia feminina ${ }^{82}$; são as hostes incomensuráveis que a grande figura de Natan conduz à Terra Santa, na gravura fictícia do placard alemão Warhafftes Conterfey oder Abbildung des Judisch-vermeinten Wunden-Propheten Nathan Levi (1666) ${ }^{83}$.

Porém, o que mais atemorizava o jesuíta António de Melo era a divulgação da mensagem entre os conversos de Portugal. Daí que rematasse o seu texto com a notícia que Francisco Henriques -vindo a Mazagão em Agosto de 1666, como piloto de um navio- lhe havia contado, ou seja, como na ilha de S. Miguel, nos Açores, onde residia, a muitas pessoas tinha chegado o rumor deste «embuste» $\mathrm{O}$ «veículo» fora uma embarcação do Levante, e através dela o rumor «se publicara naquela ilha, e pudera ser entre gente de nação, que por receio que tenho de que alguns caiam neste engano me movi a dar conta a esta mesa do que tenho alcançado nesta matéria»-escreve o jesuíta ${ }^{84}$.

Está assim comprovado que ecos do movimento de Sabbatai chegaram a Portugal, um país que nunca deixou de ser cruzado por movimentos messiânicos de cariz variado e de raízes variadas, em cuja polissemia vários estratos políticos e identitários se reviam, moldando-a aos seus objectivos, propostas, estratégias de preservação, ambições imperialistas e esperanças futuras. Sanjay Subrahmanyam demonstrou que, durante o século xvi, se observou uma conjuntura milenarista à escala euroasiática, com as características acima assinaladas, dos primórdios do expansionismo português às pretensões escatológicas dos Safávidas de meados do século e do imperador mughal Akbar de finais da mesma centúria. Neste contexto, e especificamente em relação à temática do messianismo sebástico, o autor chama a atenção que, após a sua morte, D. Sebastião passou a ser considerado em Portugal como uma espécie de Mahdi, tanto que os epítetos que lhe eram atribuídos como o de «desejado» e «encuberto» eram quase traduções da fraseologia mahdista ${ }^{85}$. Portanto, mesmo entre inimigos religiosos circulavam conceitos semelhantes, adequados aos contextos das

\footnotetext{
${ }^{82}$ The Last letters to the London Merchants, publ. Scholem, Sabbatai Tsevi, pág. 339.

${ }^{83}$ Scholem, Sabbatai Tsevi, «Documents Iconographiques», I.

${ }^{84}$ IAN/TT, Inquisição de Lisboa, livro 243 (Século XVII - Caderno do Promotor $\mathrm{n}^{\circ} 46$ ), fol. $59 \mathrm{v}^{\circ}$.

${ }^{85}$ Sanjay Subrahmanyan, «Du Tage au Gange, au XVI Siècle: une conjoncture millénariste à l'échelle euroasiatique», Annales. Histoire, Sciences Sociales 56 (2000), pág. 81.
} 
simbologias específicas. Também foi desta larga conjuntura milenarista, e mais especificamente do cadinho messiânico que abarcava transversalmente os vários grupos religiosos do Império Otomano, que no século XVII emergiu o movimento de Sabbatai Zvi. Suraiya Faroqhi chamou a atenção para este fenómeno, de forma pertinente, na sua obra Subjects of the Sultan. Realçando a figura do Mahdi -aquele que cuidará de todo o Mundo como um governante justo, e que preparará o caminho para a segunda vinda de Jesus como o arauto do Último Julgamento na escatologia islâmica- a autora avança os exemplos de dois rebeldes otomanos que reivindicavam ser esse governante final: um artesão da cidade de Amasya entre 1576-1577, e Yahya ibn Yahya de Trípoli, em 1587. E um século antes do movimento de Sabbatai, e no âmbito do Império Otomano, um movimento messiânico dentro da Igreja Ortodoxa comportou, surpreendentemente, aspectos semelhantes ao daquele: certo monge de Tessalónica pediu aos seus seguidores para evitarem o mercado, com o objectivo de se penitenciarem, visto estar iminente o fim do Mundo. Como os ganhos dos rendeiros dos impostos locais decaíram devido a este movimento, estes não deixaram de se queixar às autoridades otomanas que, por sua vez, perseguiram o pregador. Curiosamente, os seus seguidores viram-no então como uma reincarnação de Jesus, ostentando um comportamento semelhante ao dos adeptos do Messias Sabbatai, aprisionado e apóstata ${ }^{86}$.

Mercedes García-Arenal, num conjunto de artigos sobre messianismo na bacia do Mediterrâneo, e entre a Península Ibérica e o Norte de África em particular, chamou também a atenção para similitudes, confluências e sincronias nos movimentos messiânicos verificados entre ambas as margens do Mediterrâneo. Concretamente, no caso de Sabbatai, alertou para todo um ideário messiânico que circulava na Península e no Norte de África, e que aqui, entre os meios judaicos, potenciou uma imagem fantástica de Sabbatai, desta forma mais aliciante e catalisadora de esperanças messiânicas ${ }^{87}$, e de que o relato transmitido pelo jesuíta António de Melo é mais um testemunho.

Mas as similitudes textuais reforçam também o elo diacrónico, que transpor-

${ }^{86}$ Suraiya FaroQHI, Subjects of the Sultan. Culture and Daily Life in the Ottoman Empire (London 2005), págs. 76-79. Sobre movimentos messiânicos nos Impérios Seldjúcida e Otomano, vide também o interessante artigo de Ahmet Yasar OCAK, «Syncrétisme et esprit messianique: le concept de $q t o b$ et les chefs des mouvements messianiques aux époques seldjoukide et ottomane (XIII-XVII ${ }^{\mathrm{e}}$ siècles)» em Syncrétismes et hérésies dans l'Orient seldjoukide et ottoman (XIV ${ }^{e}$-XVIII siècle). Actes du Colloque du Collège de France, ed. G. Veinstein (Paris 2005), págs. 249-257.

${ }^{87}$ García-Arenal, «Un réconfort»; EAD., «Atteintes messianiques»; EAD., «Expectativas mesiánicas»; EAD., «Les juifs portugais». 
ta para o presente noções messiânicas do passado, mesmo em traços factuais. Em 1458, segundo o franciscano Alonso de Espina, os judeus, descobertos ou secretos, atendiam a chegada do Anticristo, cujos exércitos, segundo eles, se concentravam nas montanhas dos Cárpatos, entre os palácios de Gog e Magog ${ }^{88}$. Como salienta Sanjay Subrahmanyam, a interpretação apoia-se no Apocalipse $(20,8)$, onde Gog e Magog são as tribos turbulentas do fim do Mundo ${ }^{89}$. Até que ponto as tribos turbulentas não se transformavam nas miríades de gente estranha e indomável da literatura panfletária pró ou anti Sabbatai, até se chegar aos tártaros judeus do rabi de Azamor? E Espina diria também que quando o Anticristo destruísse os inimigos de Israel e restaurasse esse reino na sua antiga realeza, os conversos deixariam a sua máscara ${ }^{90}$. Contudo, no Apocalipse (20,7-8), quem comanda as tribos de Gog e Magog é Satanás. É por tudo isto que o padre António Vieira foi denunciado ao Santo Ofício em 1665, quando asseverava que não se devia fazer caso dos cristãos-novos terem o abuso de esperarem pelo Messias ${ }^{91}$ ? De qualquer forma, estes exemplos revelam esse carácter permeável e adaptável das «narrativas messiânicas» entre crentes de diferentes religiões.

$* * *$

Foi em todo este ambiente de ambivalências, no edifício da mensagem messiânica, que a nossa carta acabou por ser publicada. Formalmente, ela faria parte das diatribes jesuíticas contra o messianismo judaico -estratégia fundamental quando esta Ordem activista pretendia ser um dos componentes fundamentais da política religiosa saída de Trento. O seu intento seria de carácter bastante pragmático: a descrição do movimento em torno de Sabbatai, culminando com a divulgação da derrota «deste» Messias e a desilusão do seus seguidores, parecia ter como objectivo fundamental asseverar que o Messias verdadeiro era o dos cristãos, e que o único messianismo admissível era «apenas» aquele entendido no contexto da ortodoxia católica. Desta forma funcionaria como um dos pilares dessa ortodoxia contra todas as tendências messiânicas cristãs que seriam consideradas desviantes em Portugal -quer de raiz popular, em torno do Bandarra, quer

\footnotetext{
${ }^{88}$ Alonso de Espina, Fortalitium fidei contra Judeos, Saracenos et alios Christianae fidei inimicos (Nürnberg 1494), fols. 172-173, cit. Jacqueline GenOT-Bismuth, «Le Mythe de l'Orient dans l'Eschatologie des Juifs d'Espagne à l'époque des conversions forcées et de l'Expulsion», Annales. ÉSC 45, pág. 823.

${ }^{89}$ Subrahmanyan, «Du Tage au Gange», pág. 76.

${ }^{90}$ Espina, Fortalitium, fols. 172-173, cit. Genot-Bismuth, «Le Mythe», pág. 823.

${ }^{91}$ IAN/TT, Inquisição de Lisboa, livro 240 (Século XVII - Caderno do Promotor nº 41), fol. 21.
} 
de cariz mais erudito, como as assumidas pelo padre António Vieira-e sobretudo contra as «erupções» sócio-religiosas nos meios conversos, nomeadamente a partir do momento em que notícias sobre o aparecimento de um Messias, invencível e fantástico, chegavam do Levante. O dilema é saber, como já foi referido, se contra a vontade dos jesuítas, esta carta em português e outras similares, não eram lidas dentro do contexto da crença messiânica dos conversos funcionando isso sim, «à tort» para eles, como uma literatura apologética, o que explicaria a inclusão de um texto semelhante no processo da cristã-nova D. Mariana, de Málaga. 
ง

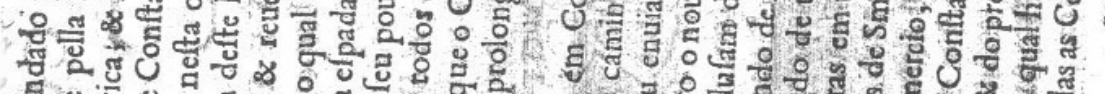

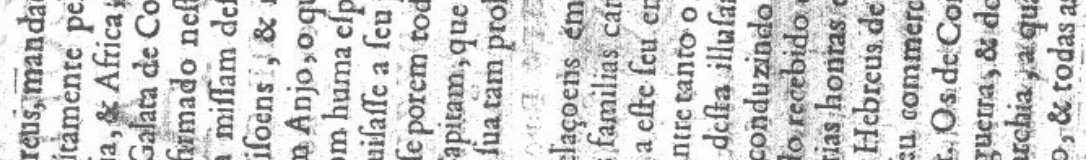

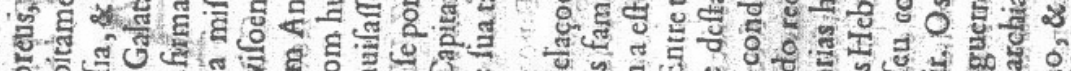

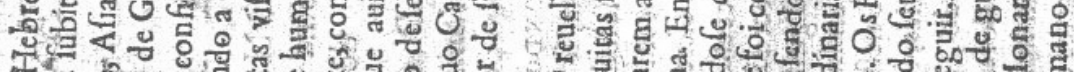
क 1 के

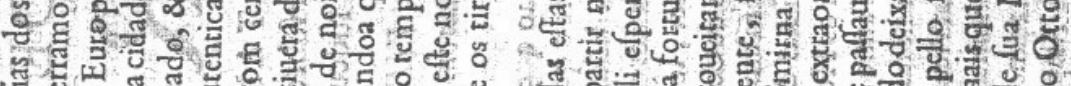

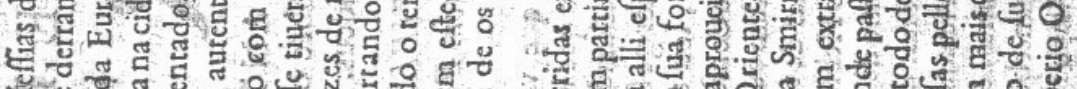

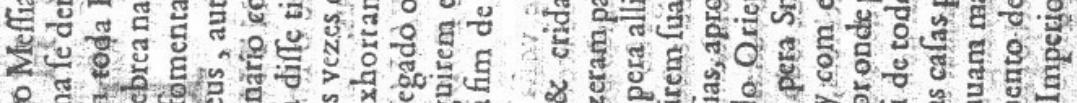

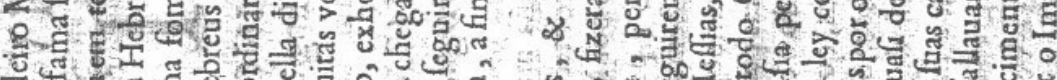
पु tos $\frac{1}{4}$.

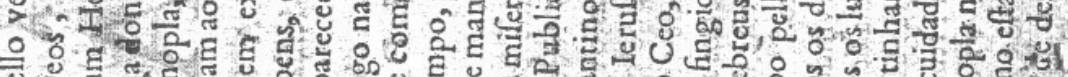
6.

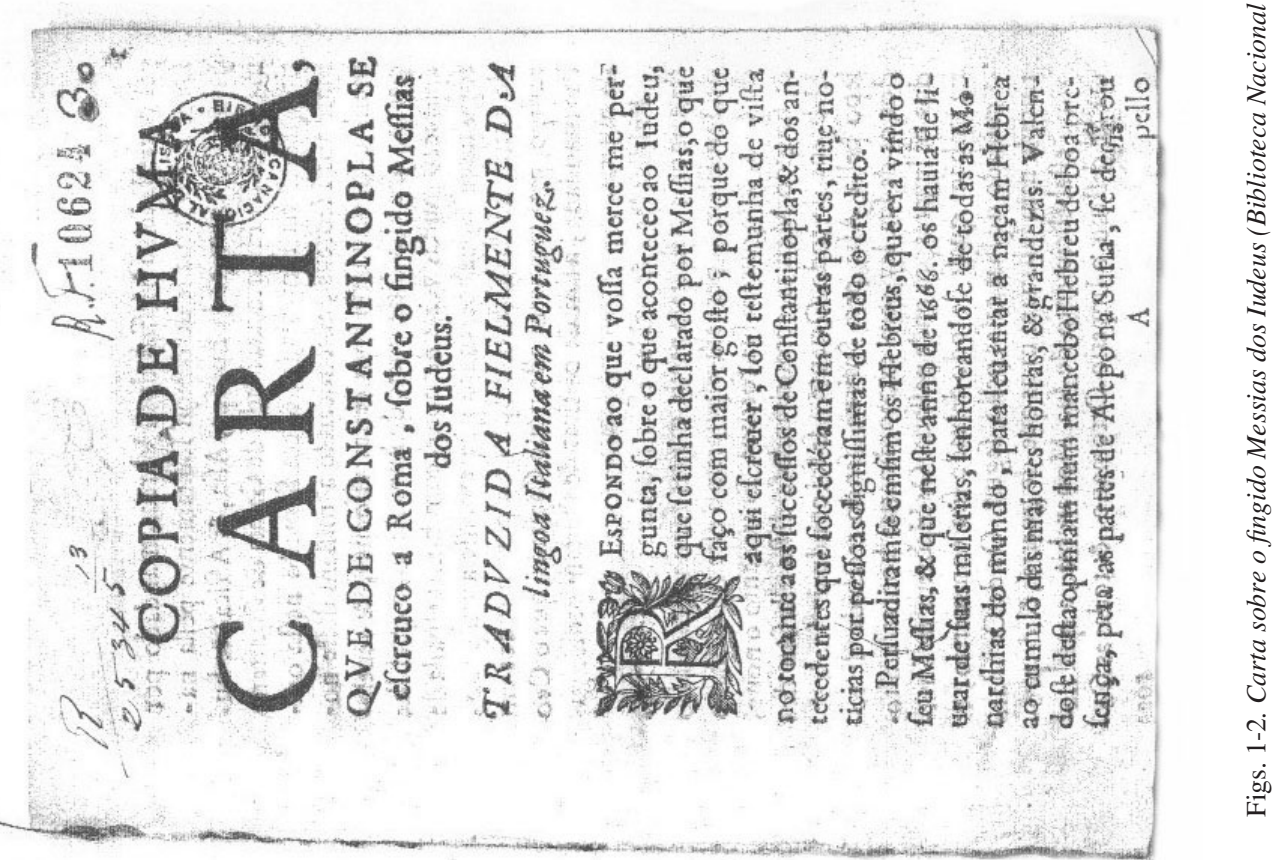

Sefarad, vol. 67:1, enero-junio 2007, págs. 155-190. ISSN 00037-0894 


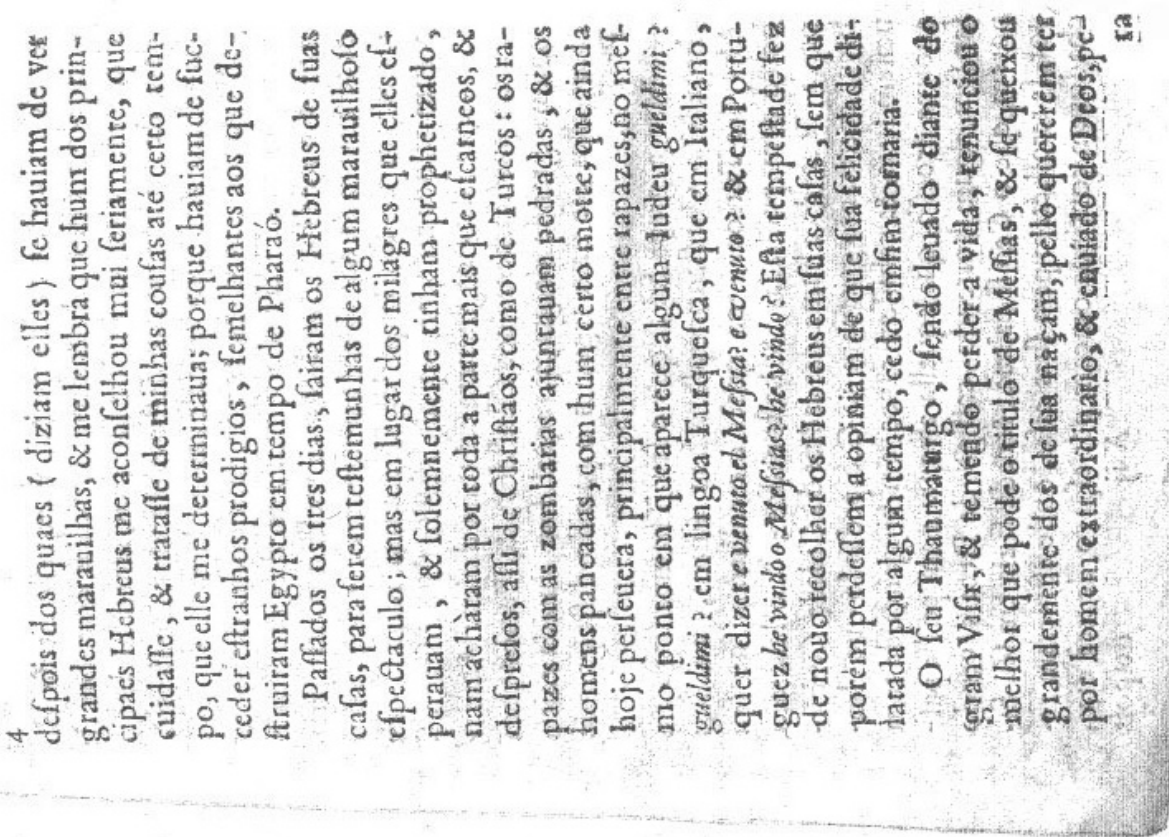

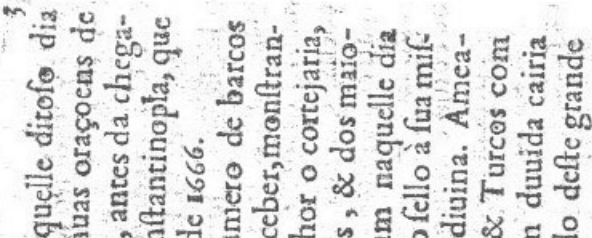
Tी

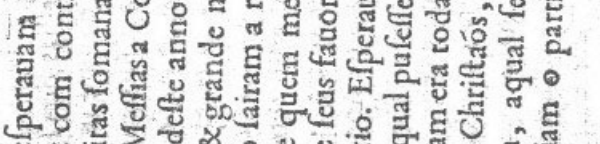

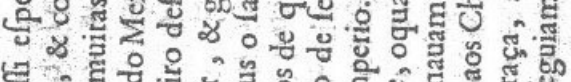

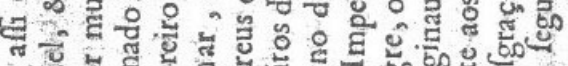

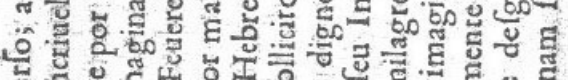

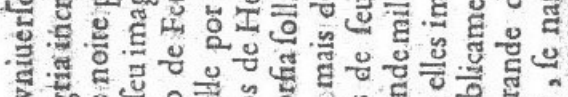

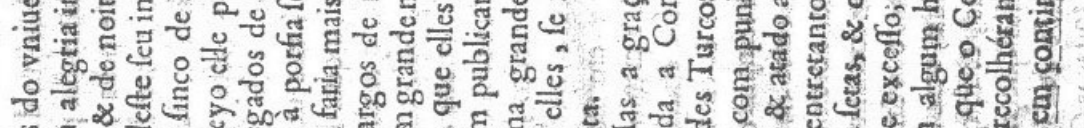

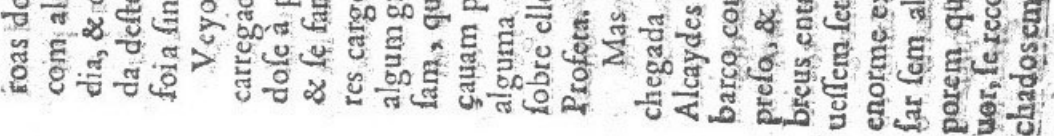




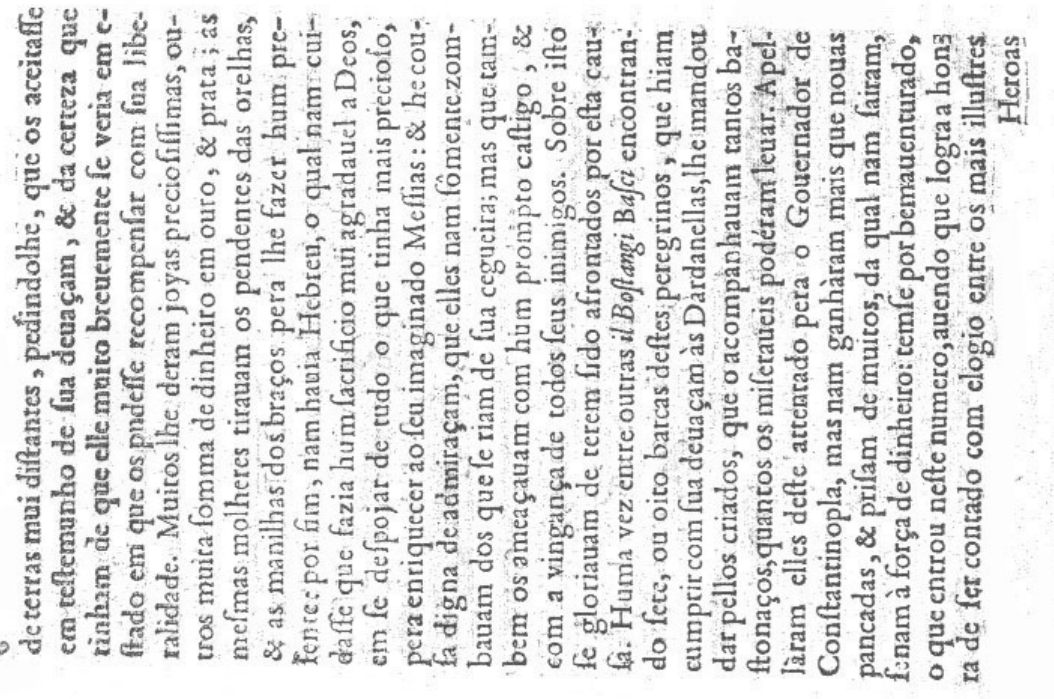




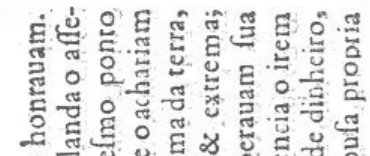

空

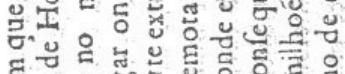

웡.

ก

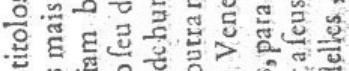

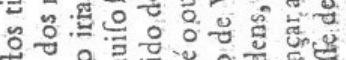

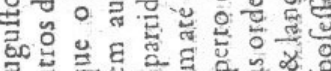

记

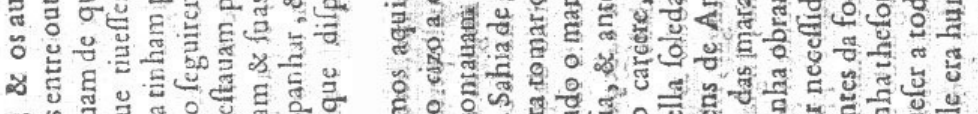

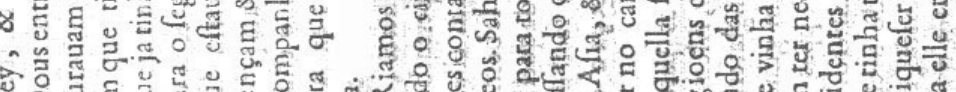

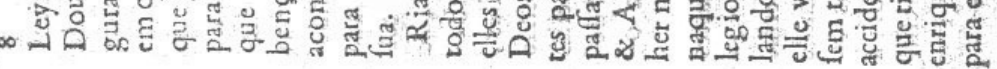

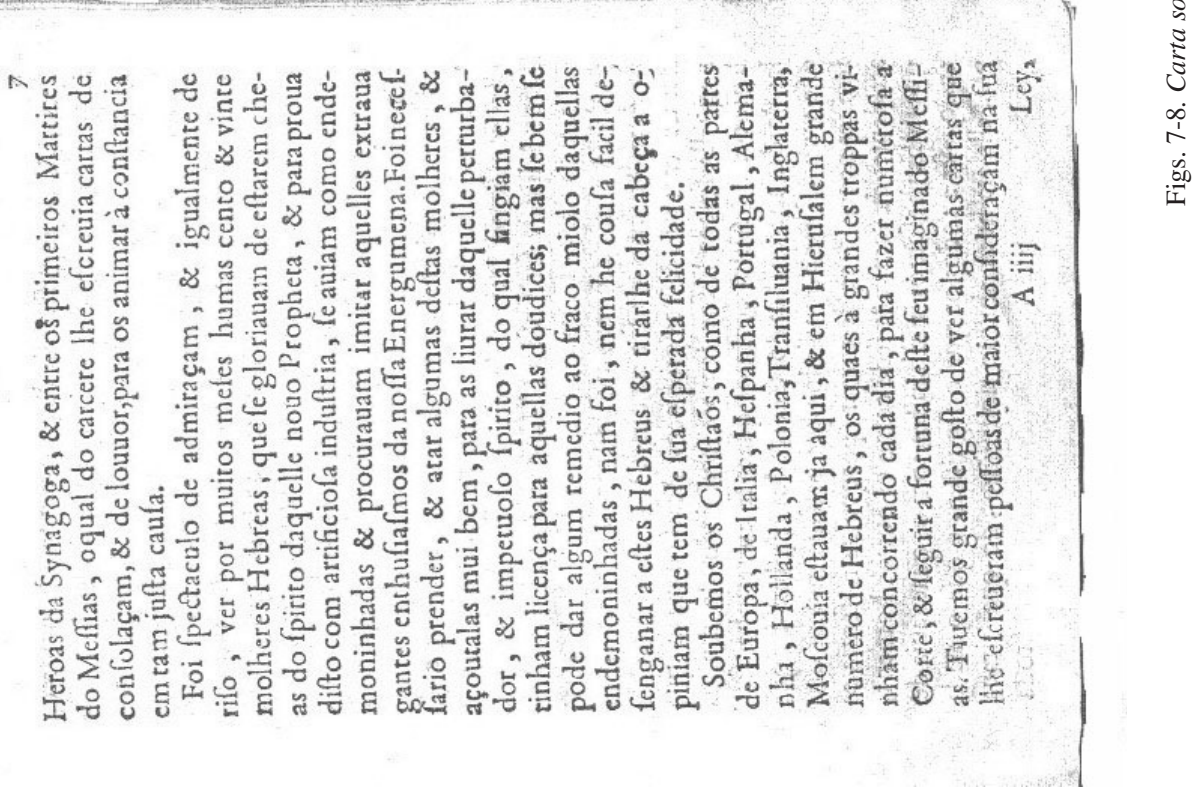

Sefarad, vol. 67:1, enero-junio 2007, págs. 155-190. ISSN 0037-0894 


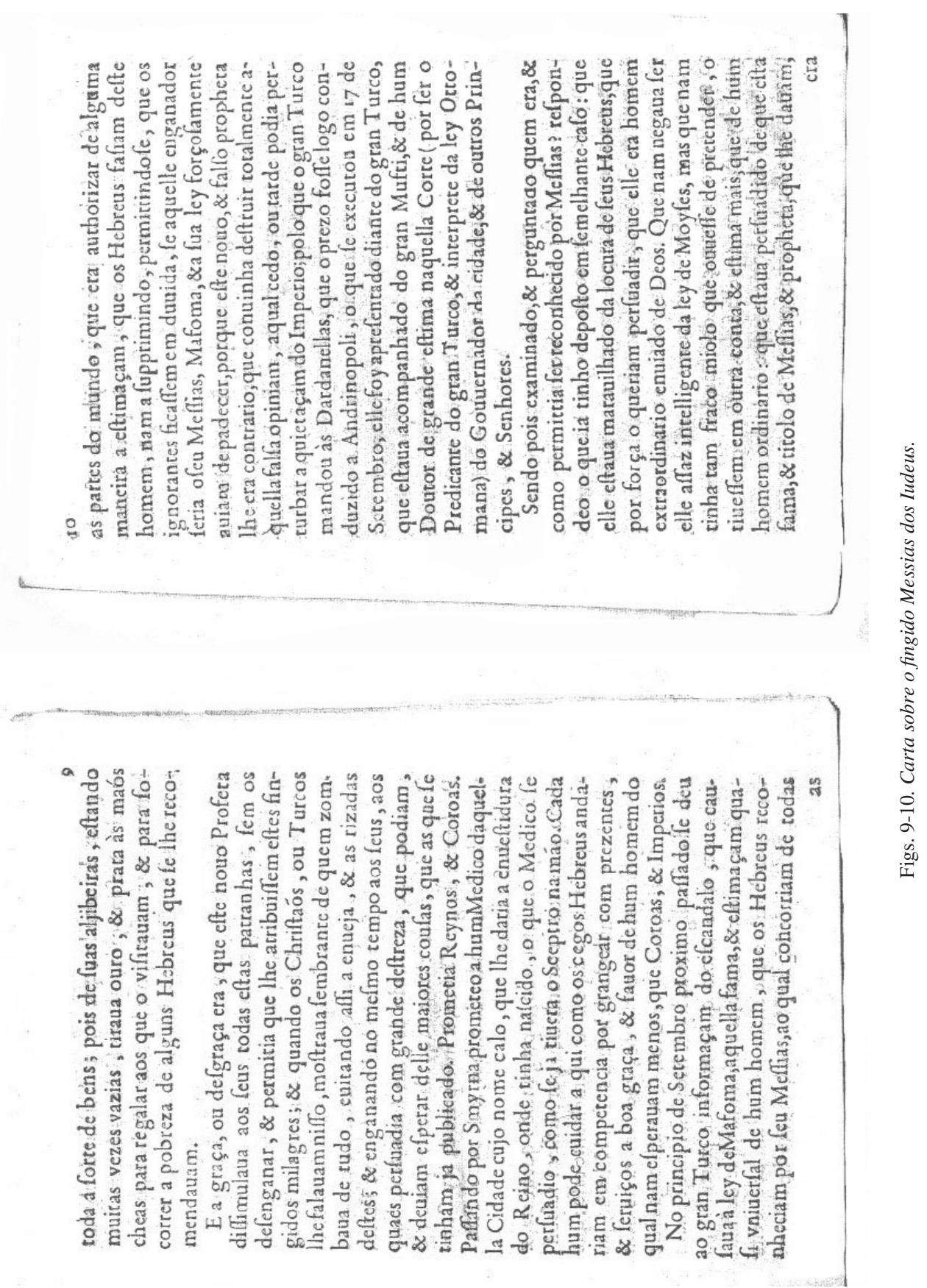

Sefarad, vol. 67:1, enero-junio 2007, págs. 155-190. ISSN 00037-0894 


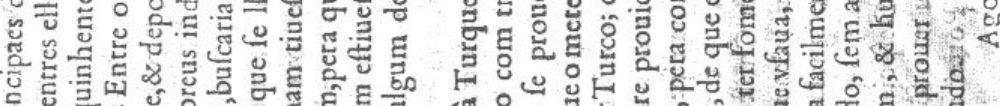

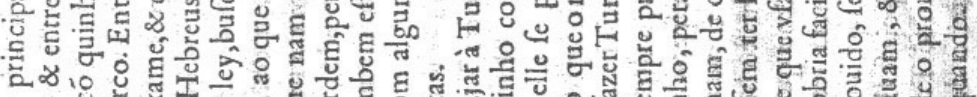

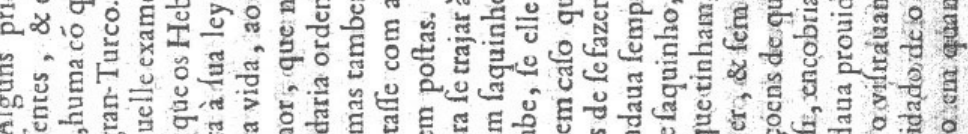

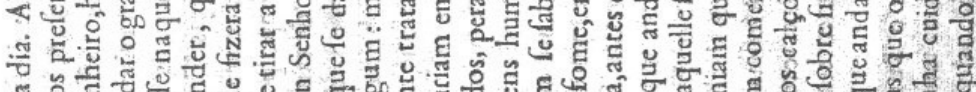

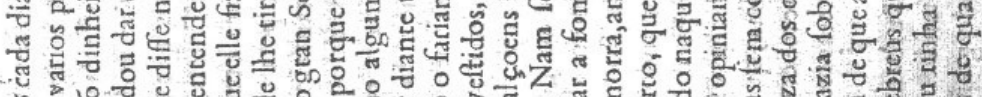 等

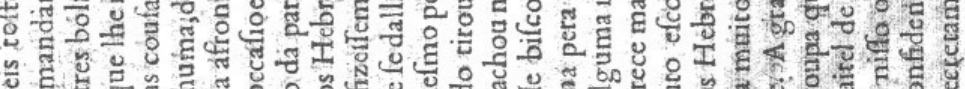

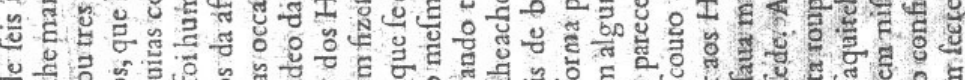 는 范 *}

$=1$

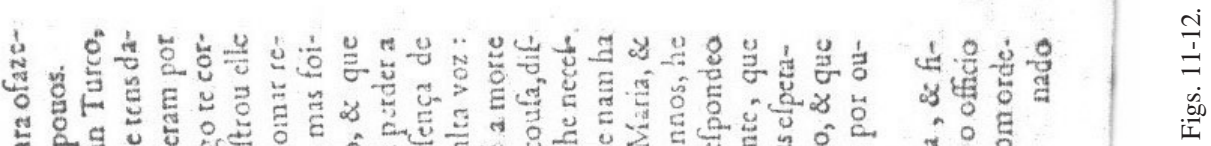

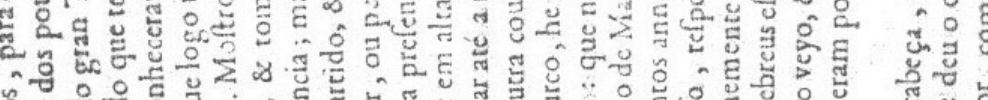

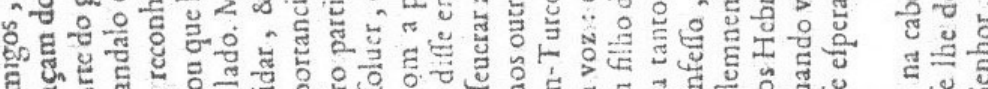

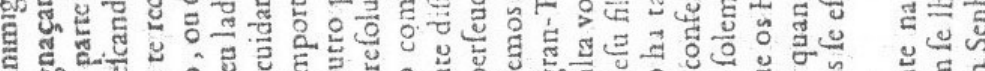

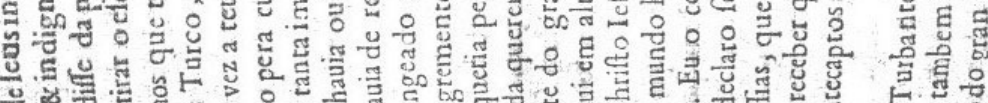

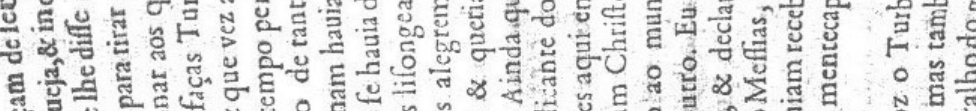

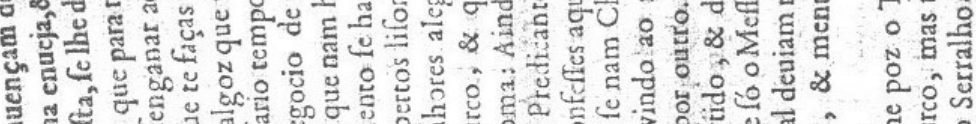

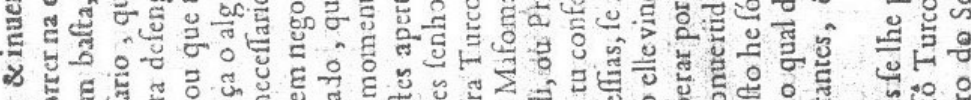
廿

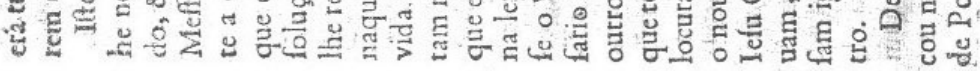

SeFARAD, vol. 67:1, enero-junio 2007, págs. 155-190. ISSN 0037-0894 

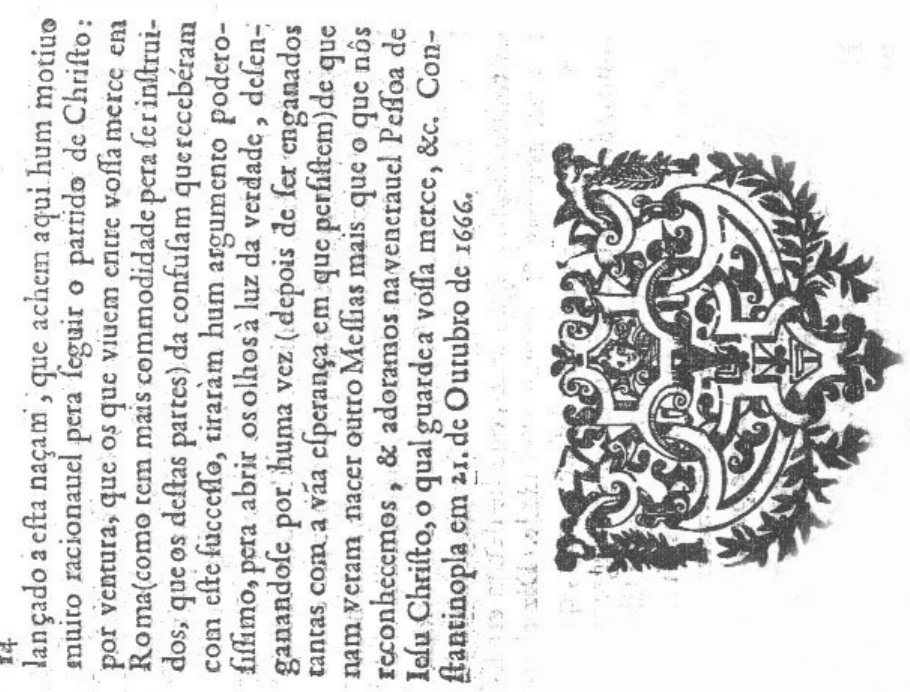

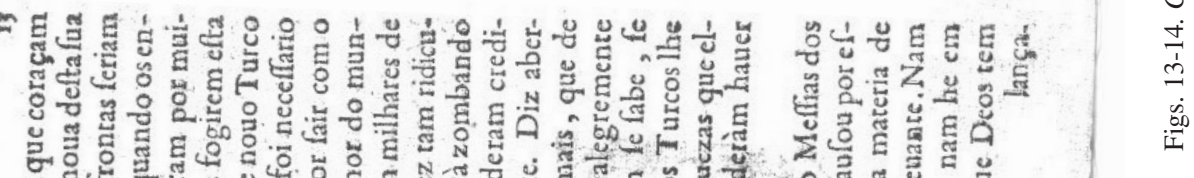

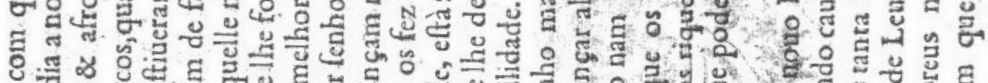

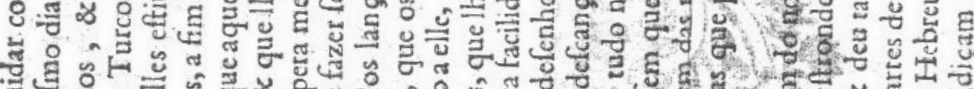

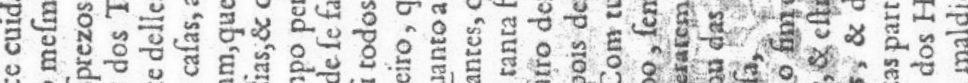

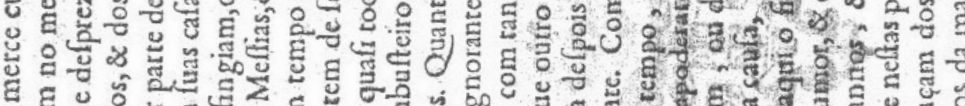

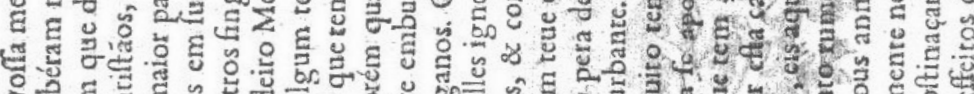
४

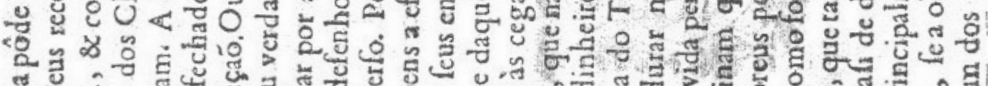

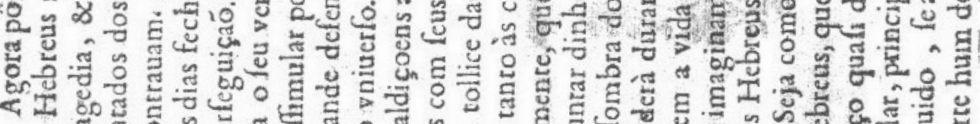

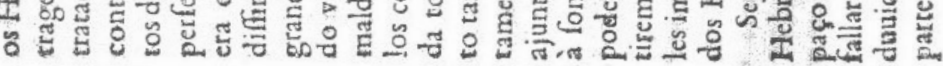




\section{RESUMEN}

Este artículo aborda el contexto de la producción-traducción de un texto en portugués sobre Sabetay Sebí, en 1666. Se alude a la producción de otros textos similares y a la información sobre los adeptos del movimiento en España, sobre todo en Málaga. Se reflexiona sobre las varias corrientes mesiánicas que cruzaban los diferentes grupos sociales en Portugal. Se presenta un texto que prueba la divulgación de noticias sobre Sabetay, en tierras portuguesas y del interés despertado entre los medios conversos sobre el movimiento. Y se plantea la hipótesis de que este texto contrario al movimiento de Sabbatai pudiera tener varias lecturas, entre ellas una que debería ser conveniente para los conversos.

Palabras clave: Sabetay Sebí, mesianismo, conversos, Portugal, Turquía, España.

\section{SUMMARY}

The present paper deals with the Iberian context of the production-translation of a text in Portuguese language about Shabbatai Zevi, in 1666. We refer the production of similar texts and the information about the adherents in Spain, mostly in Malaga. We reflect on the various messianic currents that crossed the different social groups in Portugal. We present a text that proves the spreading of news about Shabbatai in Portuguese Lands, and the interest kindled among the Portuguese Conversos. And we place the hypothesis that this text to the movement of Shabbatai, could have different readings, among them one that could be convenient to the conversos.

KeYwords: Shabbatai Zevi, Messianism, Conversos, Portugal, Turkey, Spain. 